\title{
Systeemanalyse van het IJsselmeergebied, een kennisinventarisatie.
}

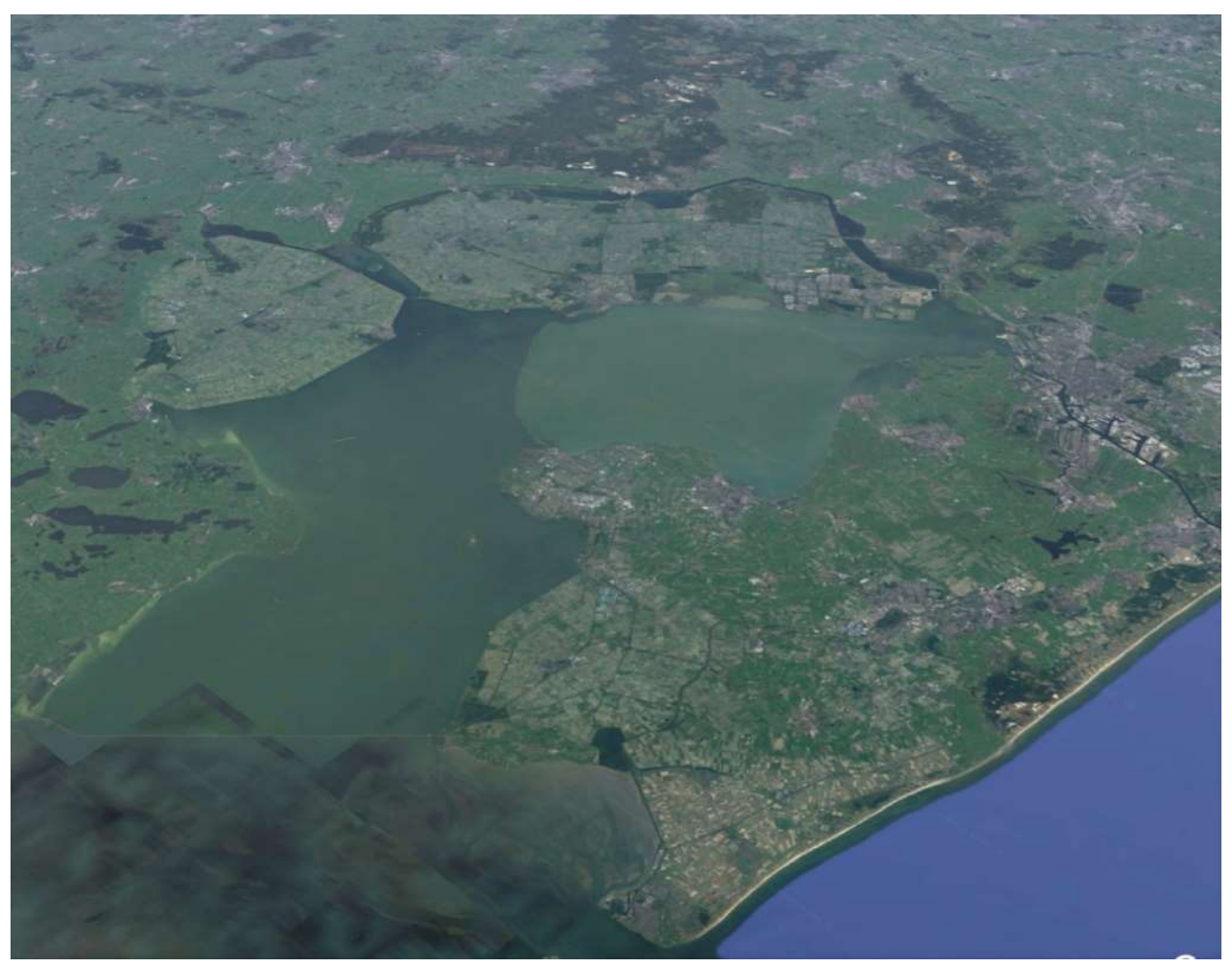

Auteurs Mariëlle van Riel, Jeroen Veraart \& Piet Verdonschot 


\section{Auteurs}

Auteur(s) Mariëlle van Riel, Jeroen Veraart en Piet Verdonschot

(correspondentie: piet.verdonschot@wur.nl)

\section{Opdrachtgever}

Ministerie van LNV; contactpersoon Leen Kool

\section{Projectgroep}

Mariëlle van Riel, Jeroen Veraart en Piet Verdonschot

\section{Wijze van citeren}

Van Riel, M.C., J.A. Veraart, en P.F.M. Verdonschot (2020). Systeemanalyse van het IJsselmeergebied, een kennisinventarisatie. Notitie Zoetwaterecosystemen, Wageningen Environmental Research, Wageningen UR, Wageningen. 20 pp.

\section{Trefwoorden}

Stroomgebied, IJsselmeergebied, ecologisch functioneren, stroomgebied brede systeemanalyse.

\section{Beeldmateriaal}

Mariëlle van Riel

DOI: $10.18174 / 528305$

Dit project is uitgevoerd in opdracht van het Ministerie van Landbouw, Natuur en Voedselkwaliteit.

(C) 2020 Zoetwaterecosystemen, Wageningen Environmental Research

- Overname, verveelvoudiging of openbaarmaking van deze uitgave is toegestaan mits met duidelijke bronvermelding.

- Overname, verveelvoudiging of openbaarmaking is niet toegestaan voor commerciële doeleinden en/of geldelijk gewin.

- Overname, verveelvoudiging of openbaarmaking is niet toegestaan voor die gedeelten van deze uitgave waarvan duidelijk is dat de auteursrechten liggen bij derden en/of zijn voorbehouden.

Wageningen Environmental Research aanvaardt geen aansprakelijkheid voor eventuele schade voortvloeiend uit het gebruik van de resultaten van dit onderzoek of de toepassing van de adviezen. 


\section{Inhoud}

$1 \quad$ Inleiding en doel 2

1.1 Achtergrond 2

1.2 Doelen en producten 2

1.3 Inleiding 2

2 Aanpak en resultaten 5

2.1 Orde brengen in factoren en schalen 5

2.2 Verkennen van sleutelfactoren 6

$\begin{array}{ll}2.3 & \text { Sleutelfactoren invullen met beschikbare data } \\ 2.4 & \text { Zoeken nar samenhang }\end{array}$

$\begin{array}{lll}2.4 & \text { Zoeken naar samenhang } & 12\end{array}$

3 Conclusies en aanbevelingen $\quad 15$

4 Referenties 16

Bijlage 1: Status van de N2000 doelen voor het IJsselmeergebied 18 


\section{$1 \quad$ Inleiding en doel}

\section{$1.1 \quad$ Achtergrond}

Het ministerie van LNV heeft vragen gesteld over het functioneren van het IJsselmeergebied. Het ministerie is benieuwd naar de bestaande kennis over het huidig functioneren van het ecosysteem en de richting waarin dit gebied zich gaat ontwikkelen. Er wordt bewust gesproken over het IJsselmeergebied en niet over het IJsselmeer om de landschapsschaal van het systeem waarbinnen het IJsselmeer ligt te duiden. Om te begrijpen hoe het systeem werkt is het nodig de uitwisselingen op kleine en grote schaal van water, stoffen en organismen te weten (bijvoorbeeld waterbalans, vogeltrek). Op de langere termijn kan zo verkend worden wat de effecten van geplande maatregelen en optredende ontwikkelingen zijn op ecologische draagkracht. De individuele meren in het IJsselmeergebied staan niet op zichzelf maar staan in verbinding met elkaar en met het omringende land. Daarnaast zijn veel planten en dieren afhankelijk van de land-water interactie of hebben ze beide habitats nodig om voor te kunnen komen. Lang zijn water en land apart van elkaar beschouwd en is te weinig aandacht geweest voor de overgangen en interacties tussen water en land. Ook is het interessant om een beeld te krijgen van de rol van afwijkende ontwikkelingen, catastrofe momenten, op het systeem. Het groeiend besef dat veel oplossingen voor N2000 doelen in de interactie land-water te vinden zijn heeft geleid tot de behoefte aan meer kennis hieromtrent.

\subsection{Doelen en producten}

Het doel is om een eerste aanzet te geven voor een systeemanalyse van het IJsselmeergebied op landschapsschaal, door het opstellen van een conceptueel model voor het functioneren van het grootschalige ecosysteem. Hiervoor verkennen we welke informatie essentieel is, en welke kennis beschikbaar is voor het uitvoeren van een systeemanalyse naar de ecologische samenhang en het functioneren van de wateren in het IJsselmeergebied en hun terrestrische omgeving als complex samenhangend systeem.

\section{$1.3 \quad$ Inleiding}

Er bestaan veel initiatieven voor maatregelen om het IJsselmeergebied te laten voldoen aan de natuurbeleidsdoelen die voor dit gebied van kracht zijn. Actuele maatregelpakketten voor het IJsselmeergebied zijn beschreven in de Programmatische Aanpak Grote Wateren (PAGW, Rijkswaterstaat 2019), de Uitvoerings-, Kennis- en Innovatieagenda (UKA, Ministerie van I\&W 2018), de agenda IJsselmeergebied 2050 en de ontwikkelingsvisie 2030 voor de verschillende meren in het gebied (Ministerie van I\&M 2017a-d). Figuur 1 geeft een overzicht van de geplande maatregelpakketten.

De focus van de maatregelpakketten ligt voornamelijk op het voldoen aan de Europese wetgevingen; Natura 2000 (Ministerie van LNV 2009, van Rijn et al. 2010, Rijkswaterstaat en Ministerie van I\&M 2017, Platteeuw et al. 2019) en KaderRichtlijn Water (Van Luijn en Rijsdijk 2006). Bijlage 1 geeft een overzicht van de N2000 en KRW doelen en de huidige status ervan voor het IJsselmeergebied (Rijkswaterstaat, Ministerie van I\&M 2017a-d). Op dit moment voldoen de wateren in het IJsselmeergebied nog niet aan de gestelde doelen. Als redenen voor het niet halen van de doelen worden de kernwoorden voedsel, rust, ruimte, habitat, leefgebied en externe oorzaken genoemd. Deze kernwoorden gaan over de randvoorwaarden voor de doelsoorten om te kunnen standhouden, het ecologisch functioneren van het gebied. Hoewel voor ieder meer in het

IJsselmeergebied specifieke doelen vastgesteld zijn, bestaat er een grote samenhang tussen de wateren en het omringende land. 


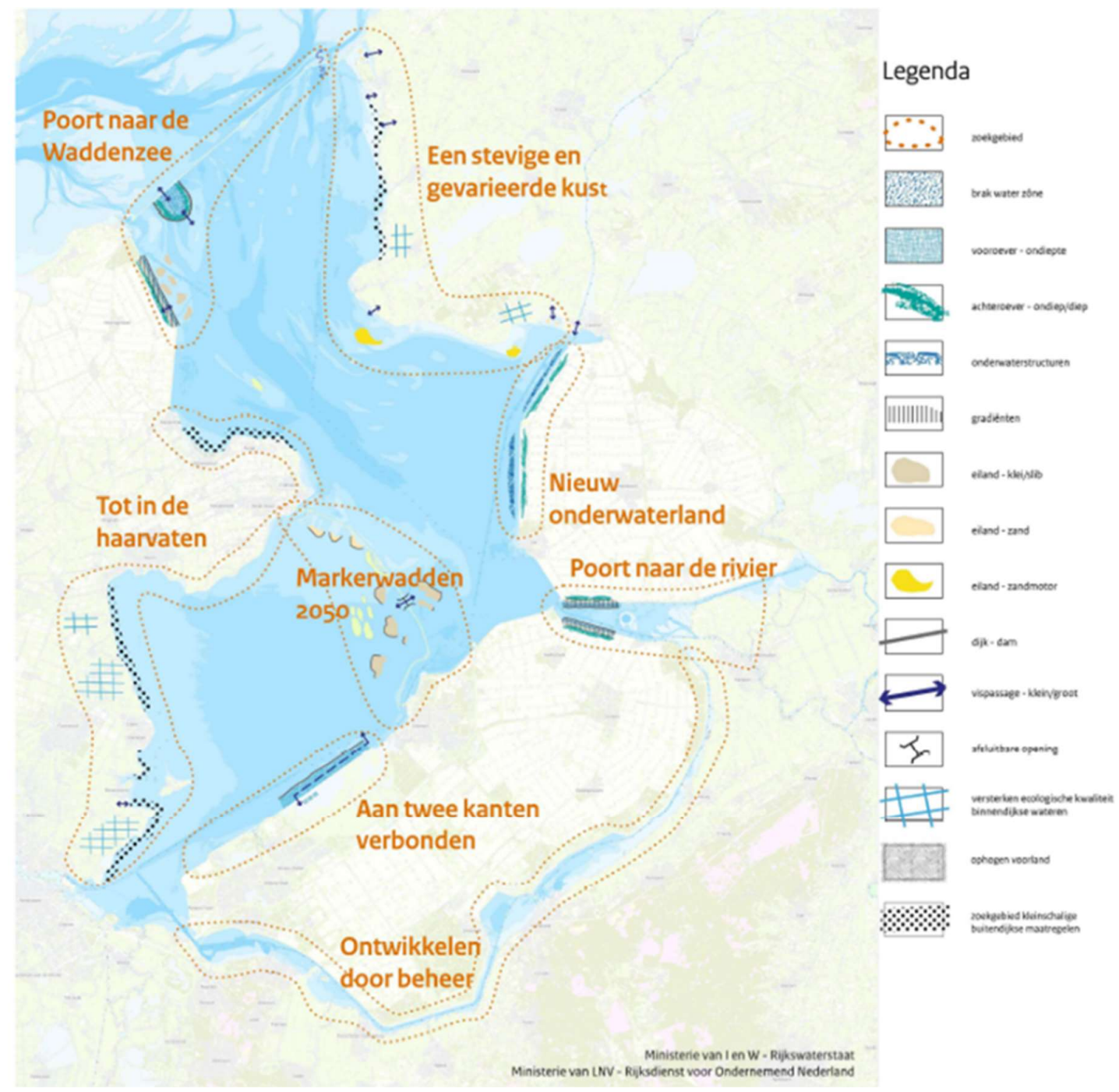

Figuur 1: Overzicht van geplande maatregelpakketten. Bron: Min I\&W (2017).

De twee grote en enkele kleinere meren in het gebied staan met elkaar in verbinding en worden vooral gevoed door neerslag en water uit de rivieren IJssel en Eem die in het gebied uitmonden (Figuur 2), naast een aantal gemalen en beken. Hoewel het gebied een grote natuurwaarde heeft, is het systeem hydromorfologisch zeer kunstmatig. De meren zijn ingedijkt en hebben een vastgelegd, tegennatuurlijk waterpeil met hoog water in de zomer (-0.2m NAP) en laag water in de winter $(-0.4 \mathrm{~m}$ NAP). In de grootste meren ontbreken ondiepe zones en geleidelijke land-water overgangen met begroeide oevers. Het gebied is van oorsprong een estuarium en is sinds 1936 door de voltooiing van de afsluitdijk afgesloten van zee invloed. Tegenwoordig worden de meren als zoetwatermeren geclassificeerd. De bodem bevat nog altijd karakteristeken van marien sediment. De combinatie met de zoete waterlaag resulteert in afwijkende sedimentatie- en biogeochemische processen en een verstoord voedselweb (van den Berg 2010, Saaltink 2018). Ecologische processen en successie worden geremd, waardoor het ecosysteem grotendeels in een pioniersstadium van ecologische ontwikkeling blijft hangen (Van Riel et al. 2019). Het ecosysteem heeft geen buffer kunnen ontwikkelen, waardoor veranderingen en stressoren een grote invloed op het ecosysteem hebben. Dit effect is direct terug te zien in het voedselweb en de productiviteit van het IJsselmeergebied.

Het IJsselmeergebied fungeert naast natuurgebied ook als vis- vaar-, en recreatiewater, er wordt water onttrokken voor drinkwater en water toe- en afvoer naar de omgeving. Kortom, een stroomgebied met veel dynamische verbindingen. 


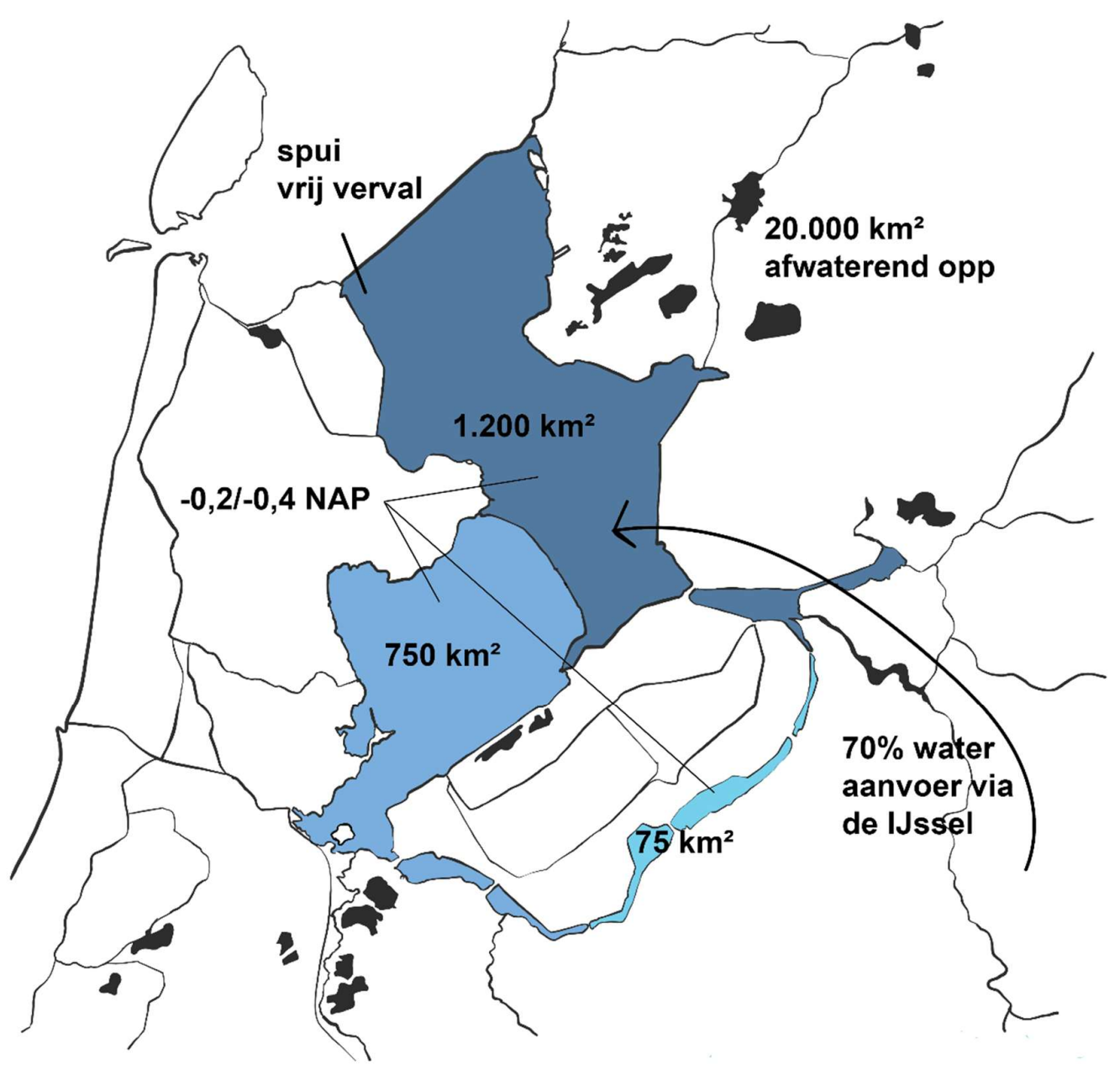

Figuur 2: De drie water compartimenten van het IJsselmeergebied: Het Noordelijke compartiment, i.e. IJsselmeer, Ketelmeer en Zwarte water (donkerblauw), het Zuidwestelijke compartiment, i.e. Markermeer, IJmeer, Gooimeer en Eemmeer (midden Blauw), en het compartiment met de Veluwe Randmeren (lichtblauw).

Het achterblijven van de gewenste ontwikkeling van Natura 2000 doelsoorten in het IJsselmeergebied, raakt direct aan het ecologisch functioneren van het stroomgebied. De in bijlage 1 benoemde restricties voor de doelsoorten, de reden voor het achterblijven, ligt in het ecologisch functioneren van het IJsselmeergebied als habitat en foerageergebied. Door de gemeenschappelijke ecologische uitdagingen en de vele interacties tussen de verschillende wateren en met hun omgeving, kunnen de wateren in het gebied bijna niet als afzonderlijke ecosystemen gezien worden en de focus beperkt tot de status van doelsoorten, maar is een ecologische systeemanalyse op schaal van het gehele IJsselmeerstroomgebied noodzakelijk om vooruitgang te boeken. In deze studie wordt verkend hoe een stroomgebied brede ecologische systeemanalyse bij kan dragen aan kennis over het functioneren van het IJsselmeergebied als ecosysteem en aan oplossingsrichtingen om een robuust en duurzaam functioneren te bereiken. 


\section{$2 \quad$ Aanpak en resultaten}

\subsection{Orde brengen in factoren en schalen}

Voor stromende wateren is een conceptueel model ontwikkeld waarmee orde gebracht kan worden in de vele relevante factoren en de complexiteit van ecosystemen die bepalend zijn voor het ecologisch functioneren van deze wateren (Verdonschot 2009). De kracht van dit model is dat het zich niet beperkt tot het buitendijkse gebied, maar een analyse geeft voor het ecologisch functioneren van het hele stroomgebied. Het model geeft aan waar de stuurknoppen zitten voor de ecologie van het meer.

Dit 5-S model onderscheidt vijf groepen factoren: Systeemvoorwaarden, Stroming, Structuren, Stoffen en Soorten. De werking van en interactie tussen deze vijf factorgroepen bepalen het functioneren van het ecosysteem. In figuur 3 is het 5 -S model ingevuld voor meren. Naast het onderwatergedeelte van het meer (onderwater kolom en onderwaterbodem) worden ook de litorale zone (oeverzone), moeras (overstromingszone), en aangrenzende terrestrische zone (omgeving) in de analyse opgenomen. Het ministerie van LNV heeft vragen gesteld over het functioneren van het IJsselmeergebied.

\section{5-S model Meersystemen}

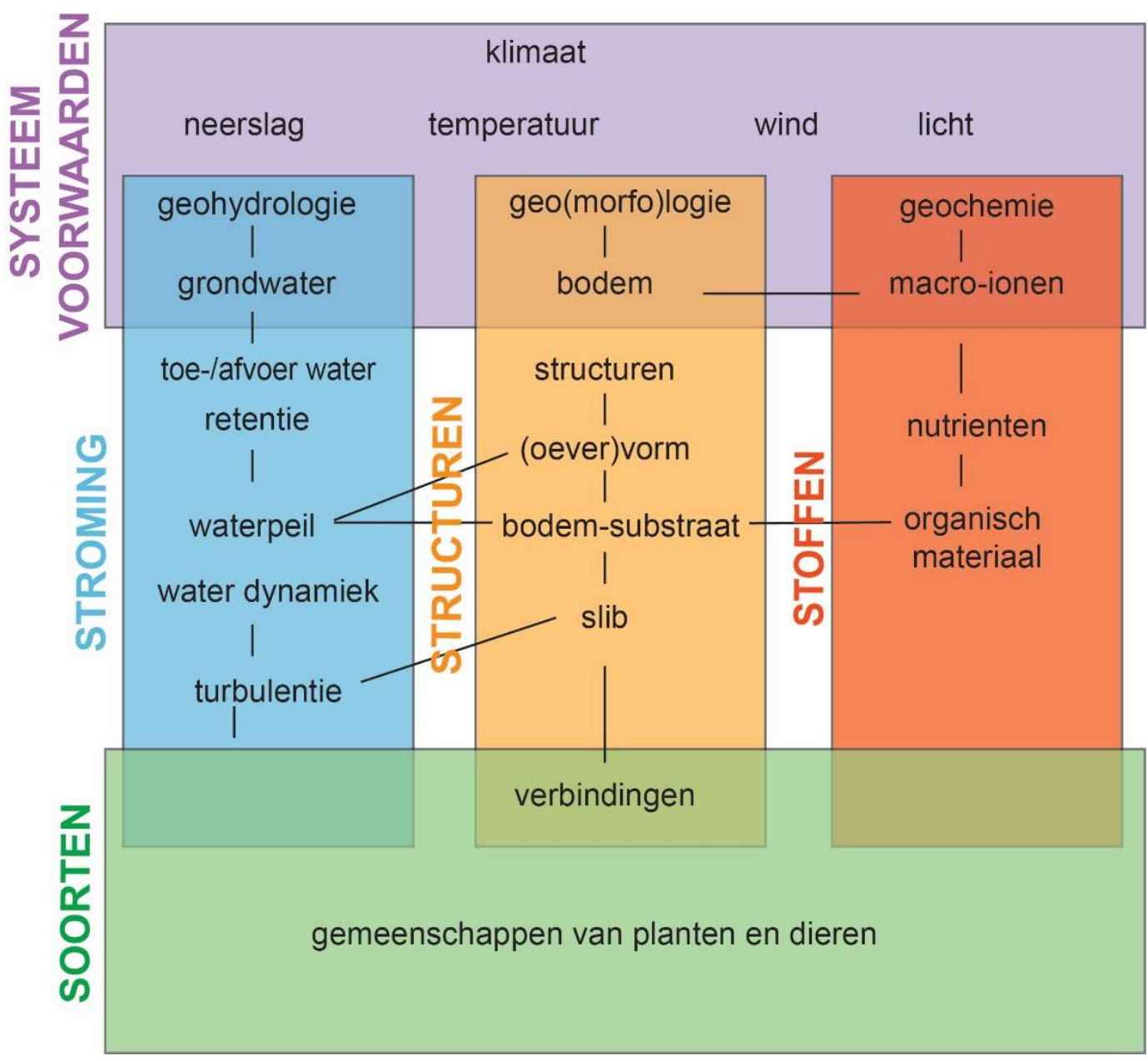

Figuur 3: Het 5-S model voor meren. 
De eerste aanzet naar analyse is het model in te vullen met voor het IJsselmeergebied relevante en, indien mogelijk, gekwantificeerde parameters. In een vervolgstap worden de samenhang en gewicht van de processen geanalyseerd om zo een compleet beeld van het functioneren van het ecosysteem te verkrijgen. De invloed van deze factoren beperken zich niet tot slechts de meren als waterplas, maar werken op het gehele tot het meer gerekende land-water ecosysteem.

Het 5-S model werkt met verschillende schalen, van groot (stroomgebied, landschap) naar lokaal (habitat). Tussen de schalen in ruimte en tijd bestaan top-down dominantie verhoudingen en bottom-up terugkoppelingen. Door de ecologische sleutel-, stress- en stuurfactoren uit het model aan elkaar te koppelen op de juiste schalen, en te integreren in de stroomgebied brede ecologische systeemanalyse ontstaat een integrale benadering die leidt tot doelgerichte maatregelen.

\subsection{Verkennen van sleutelfactoren}

Om inzicht te krijgen in welke factoren van belang zijn voor het IJsselmeergebied, wordt het model uit figuur 3 gespecificeerd voor dit gebied. Zo ontstaat een structuur als conceptueel model over het ecologisch functioneren van het gebied. We vullen het model met kennis over de factoren. Wat weten we van de sleutelfactoren en stressoren en wat kan nog niet ingevuld worden? In deze paragraaf geven we voor ieder van de vijf-S groepen in figuur 3 een voorbeeld van factoren die in het model voor het IJsselmeergebied passen, en belangrijk zijn voor het ecologisch functioneren van het stroomgebied.

\section{Systeemvoorwaarden}

Het IJsselmeergebied is een complex van zoetwater bassins op een van oorsprong mariene bodem. Het gebied is onderdeel van het Rijn-IJssel estuarium, maar is niet langer verbonden met de zee, waardoor afvoer uit het estuarium stagneert en zoutwaterinvloeden zijn verdwenen. De meren worden getypeerd als oligotrofe ondiepe zoetwater meren (KRW-type M21).

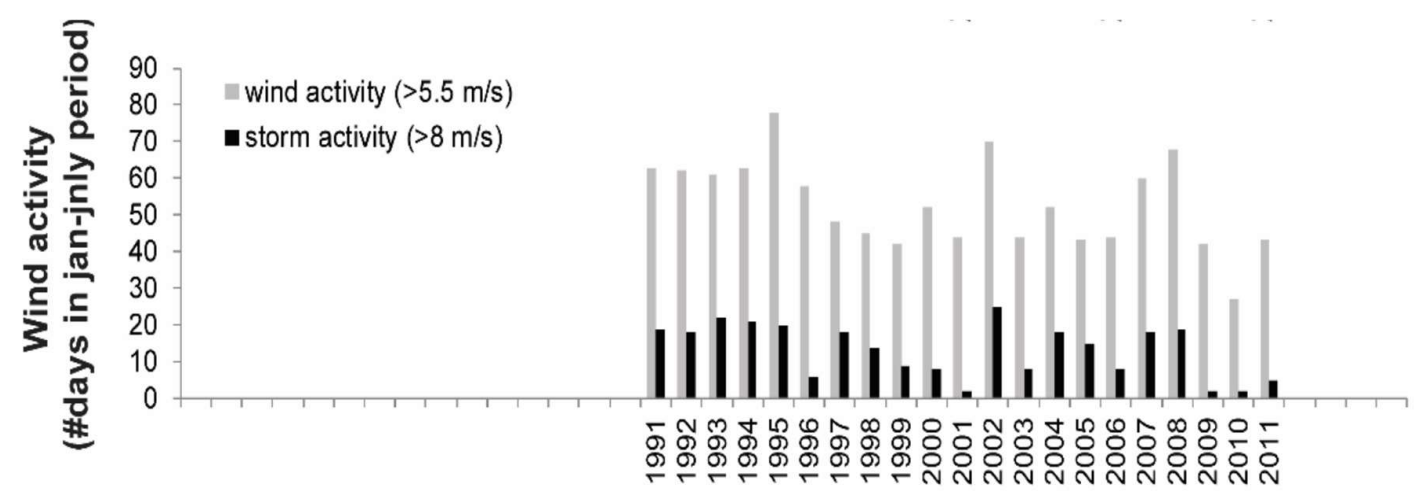

Figuur 4: Wind activiteit over de jaren in het IJsselmeergebied.

De meren worden voornamelijk gevoed door neerslag en rivierwater. Het IJsselmeergebied kent een gematigd klimaat, met een overheersende matig tot sterke zuidwestenwind. Deze wind kan in perioden krachtig tot stormachtig zijn (Figuur 4) en de waterstroming, de substraatsamenstelling en het bodemleven in de grote compartimenten beïnvloeden. Het lichtregime op de bodem is afhankelijk van diepte, sediment en windactivitieit. In het Markermeer dringt het licht niet tot op de bodem door (Noordhuis 2010, van Riel et al. 2019), in het IJsselmeer en de randmeren kan het licht wel de bodem bereiken.

Klimaatveranderingen zullen effect hebben op de systeemvoorwaarden van het gebied. Voor het IJsselmeergebied wordt voorzien dat langere perioden van droogte leiden tot een verminderde zoetwaterbeschikbaarheid en zelfs mogelijke verzilting van de meren. Men verwacht dat deze effecten vooral consequenties zullen hebben voor de hydrologie en de gebruiksfuncties van het gebied; scheepvaart, drinkwatervoorziening, recreatie en natuur. 


\section{Stroming}

Als voorbeeld voor het blok stroming is gekozen om de hoofdwaterstromen in het gebied te verkennen. Voor een uitgebreidere analyse van de factor stroming kunnen aanvullend verblijftijden, waterdynamiek en grondwaterinvloeden opgenomen worden. Figuur 5a, b, en c geven aan hoe de waterstromen in het IJsselmeergebied lopen. De figuren zijn per compartiment weergegeven, maar in het model zal dit als één geïntegreerd geheel beschouwd worden. De waterstromen geven een beeld van hoe groot het stroomgebied is, welke gebieden het water en de waterkwaliteit beïnvloeden. Op hoofdlijnen kan de stroming voor het gebied weergegeven worden, maar het kwantificeren van de water- en stofstromen is nog een uitdaging. Recent is voor het Markermeer een waterbalans gekwantificeerd (van der Geest et al. 2018). Als gevolg van klimaatveranderingen verwacht men veranderingen in de toevoer en afvoer van zoetwater naar en een hogere vraag naar zoetwater. Deze toekomstige ontwikkelingen hebben consequenties. Periodes van droogte kunnen leiden tot een lagere toevoer van water, langere verblijftijden, een toenemende vraag naar zoetwater en daardoor een grotere druk op het IJsselmeer als drink- en inlaatwater onttrekkingsgebied, moeizamer spuien van water naar de Waddenzee en mogelijk verzilting, terwijl veel neerslag in korte tijd en snelle smelten van sneeuw zorgt voor piekafvoeren van rivierwater. Het peilbeheer zal op deze veranderingen in moeten spelen. Op dit moment wordt vooral ingezet op dijkversterkingsprojecten en aanpassingen van sluiscomplexen om in te spelen op klimaateffecten, maar leven ook ideeën om waterstromen aan te passen, zoals IJsselwater deels via de randmeren laten lopen of een meer permeabele Houtribdijk.

Op basis van de kennis van het huidige ecologisch functioneren dat een ingevulde SESA geeft, kan beredeneerd worden wat toekomstige veranderingen kunnen betekenen voor het ecosysteem en welke maatregelen gewenst zijn. Periodieke updates van de SESA, door het toevoegen van actuele meetwaarden voor de aanwezige sleutelfactoren, zijn belangrijk voor tijdig inzicht in ontwikkelingen binnen een sleutelfactor en eventuele sturingsmogelijkheden.

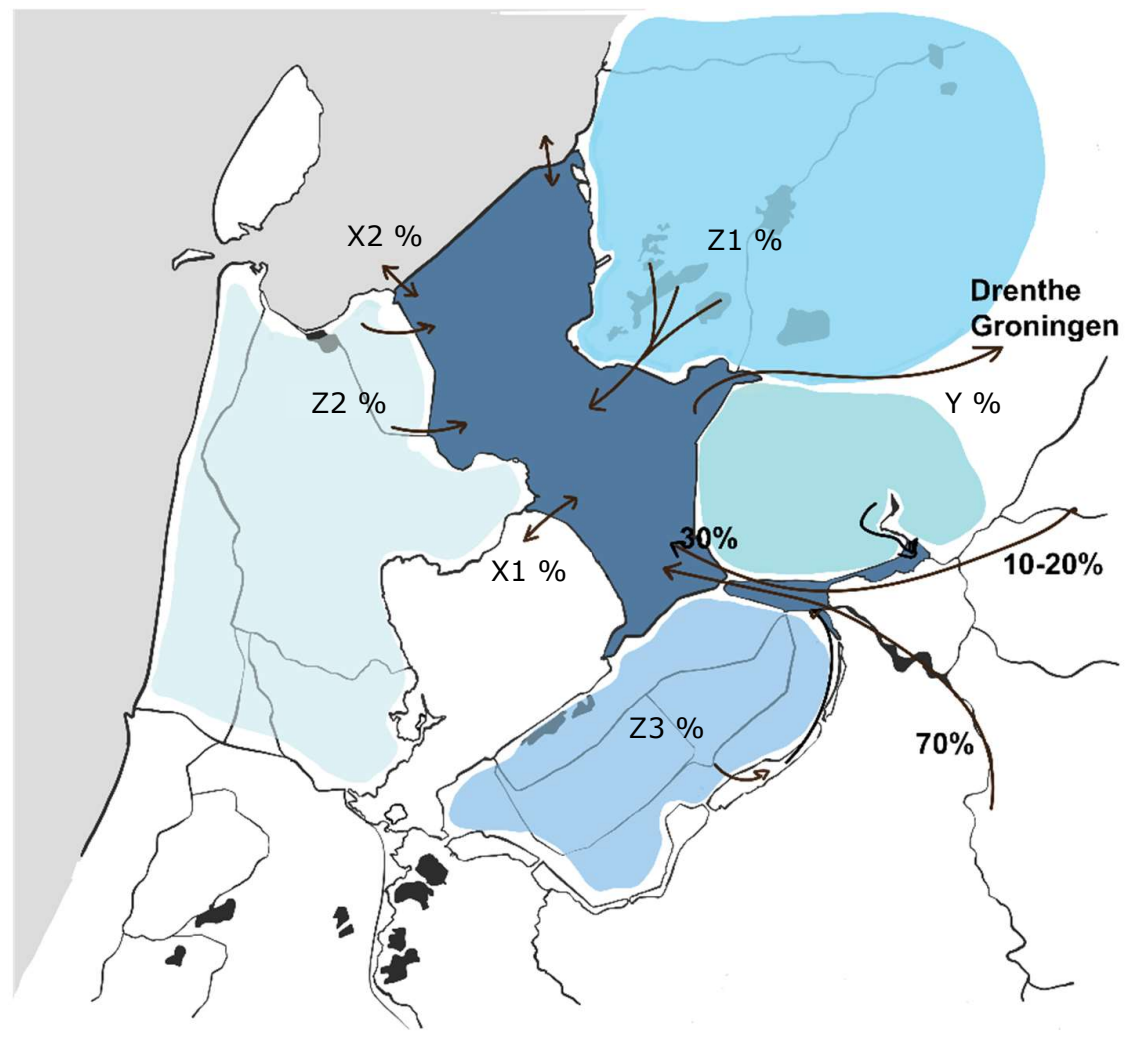

Figuur 5a: Overzicht van hydrologie van het IJsselmeer. Informatiebron: Noordhuis (2010). 


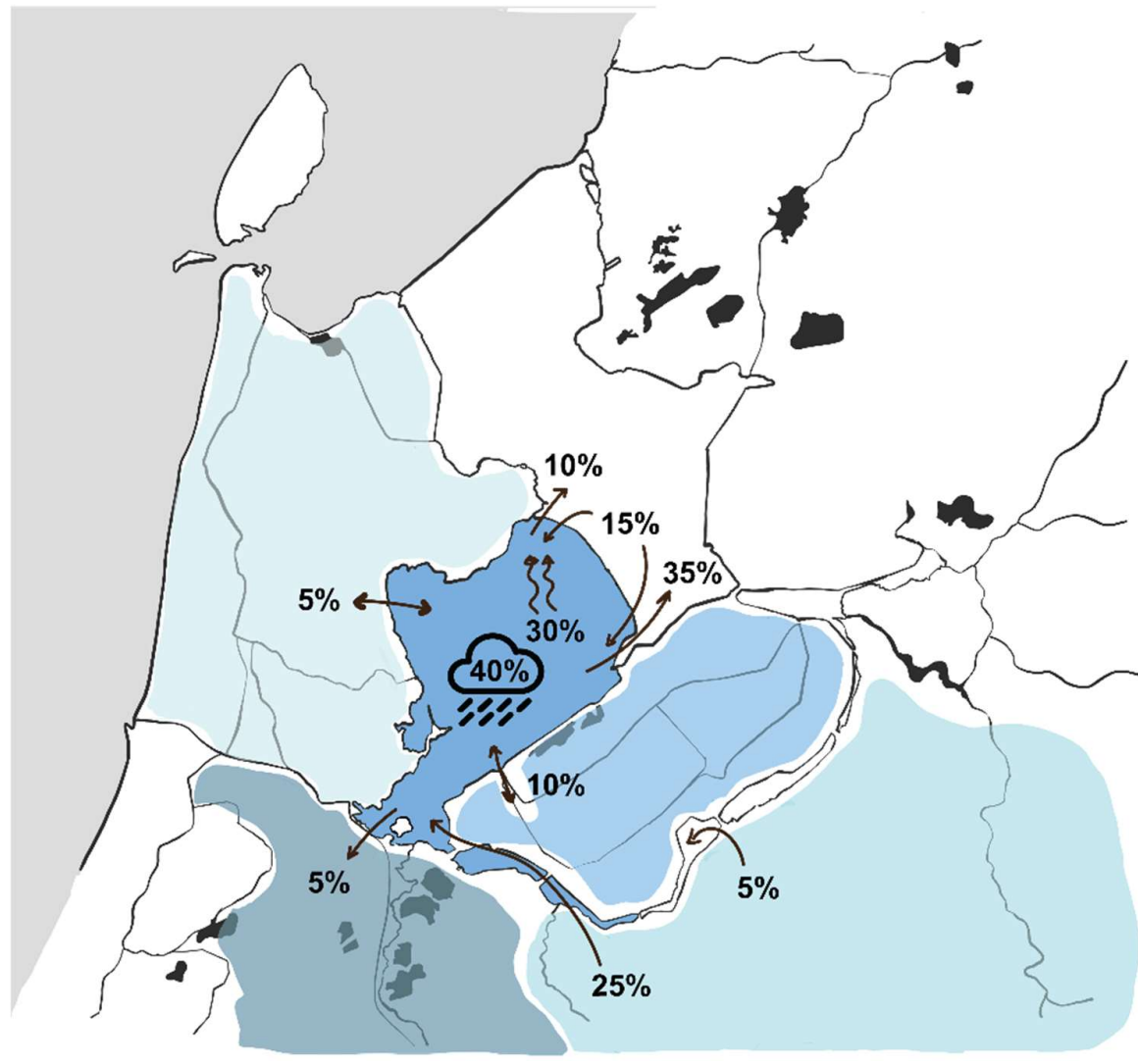

Figuur 5b:

Overzicht van

hydrologie van het Markermeer.

Informatiebron: Van der Geest et al.

(2018).

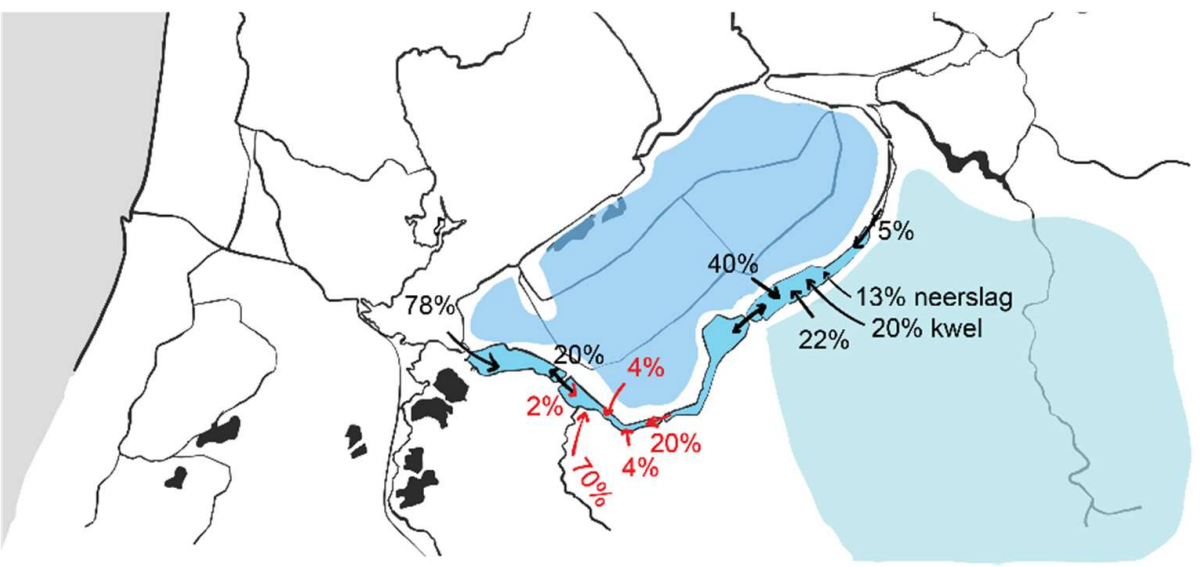

Figuur 5c:

Overzicht van hydrologie van de Randmeren.

Bronnen:

Noordhuis

(2010), RWS-

data.

\section{Structuren}

De statische hydrologische en morfologische inrichting van het gebied zijn van groot belang. De oever- en bodem(geo)morfologie, en samenstelling zijn factoren die in de SESA voor het IJsselmeergebied opgenomen moeten worden. Voor het onderdeel structuren is veel informatie beschikbaar om de SESA mee te vullen. De oevervorm kan vrij nauwkeurig in kaart gebracht worden. Daarnaast zijn bodem- en sedimentkaarten beschikbaar als informatiebron voor de structuren van het gebied. Voorbeelden hiervan zijn weergegeven in figuur 6a,b. Geomorfologische informatie is ook beschikbaar (Noordhuis 2010). 

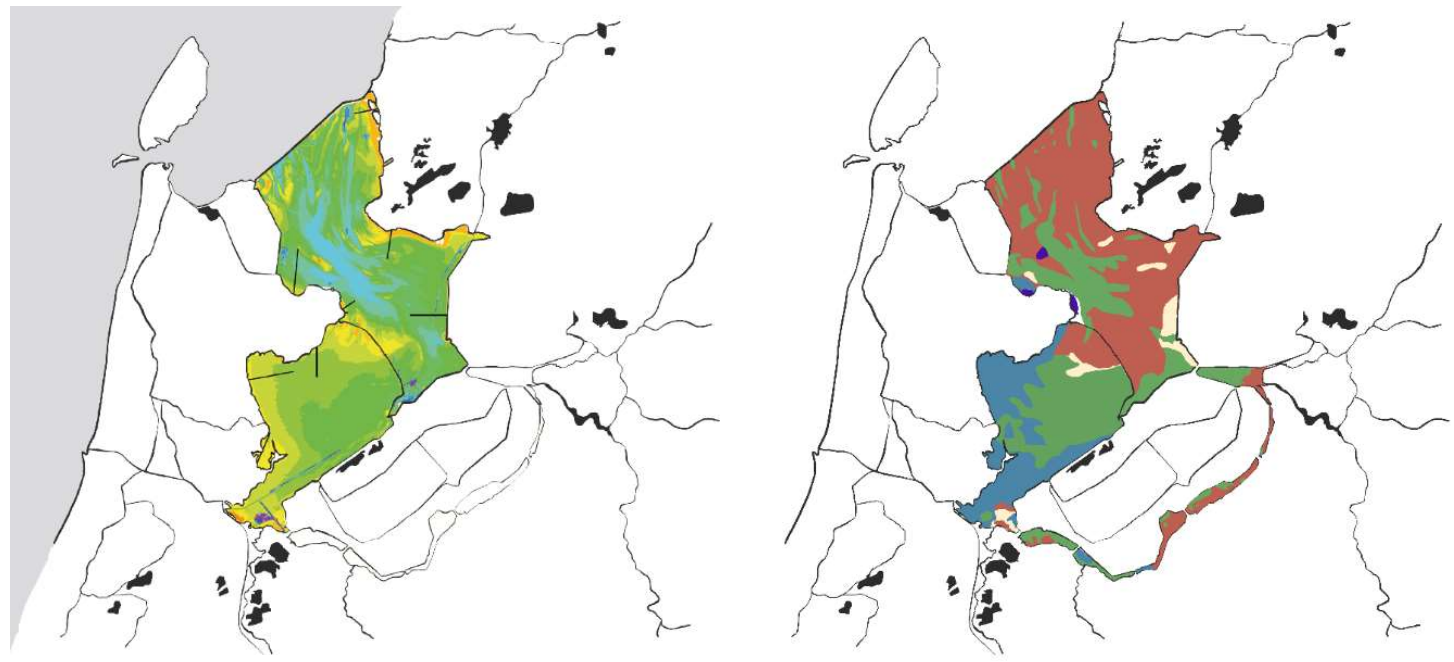

Figuur 6: Informatie over de bodemdiepte (a) en bodemsediment typen (b) in het IJsselmeergebied. Naar Noordhuis (2010).

\section{Stoffen}

Er wordt verondersteld dat de rivieren de belangrijkste aanvoerders zijn van nutriënten in het IJsselmeergebied, waarbij $73 \%$ via de IJssel het gebied in komt (Figuur 7). Voor stroomgebiedbrede analyse zal onderzocht worden welke andere aanvoerroutes voor nutrienten een rol spelen. Hierbij zijn vooral de concentraties van nutrienten in het water van belang. Een groter volume met lage concentraties kan minder zwaar wegen dan een lage, geconcentreerde toevoer. De waterbalans geldt als basis, waaraan stoffenconcentraties gekoppeld kunnen worden. In de jaren '60 en '70 waren de stikstof en fosfaatconcentraties in het rivierwater hoog en dreigde het IJsselmeergebied te eutrofiëren door de hoge nutriëntentoevoer (Tabel 1). Na de-eutrofiëringsmaatregelen voor de rivieren namen de concentraties van fosfaat en stikstof in het merengebied af (tabel 1, Noordhuis 2010, van Riel 2019). Het is aannemelijk dat ook inlaatwater uit de polders een belangrijke nutriëntenbron vormt.

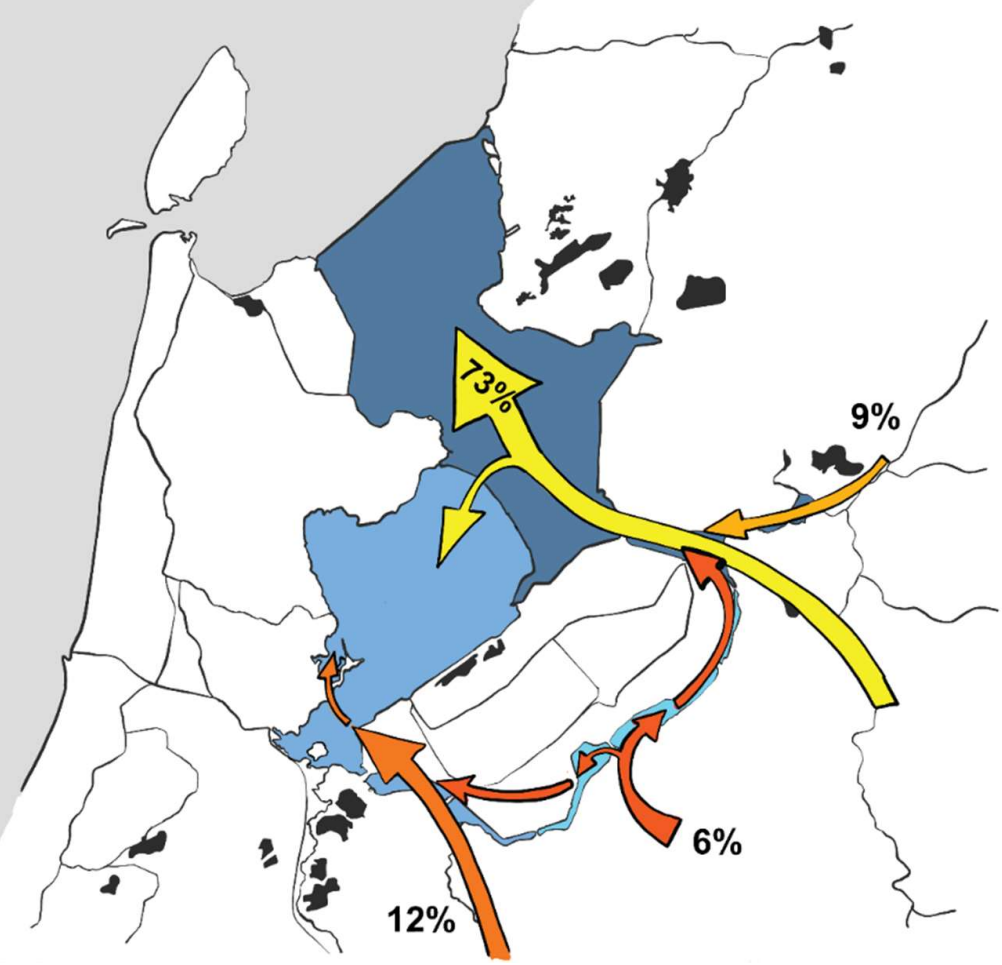

Figuur 7: Hoofdstromen voor de aanvoer van nutriënten ( $P$ en $N$ verbindingen). 
Tabel 1: Nutriënten concentraties (PO4 en totaal $N$ ) in de IJssel, het IJsselmeer en het Markermeer voor de periodes voor (1960-1970) en na (jaren 90) het implementeren van de-eutrophicatie maatregelen voor de rivieren. Brondata: Noordhuis (2010).

\begin{tabular}{lllll}
\hline & \multicolumn{2}{c}{$\mathrm{PO}_{4}(\mathrm{mg} / \mathrm{l})$} & \multicolumn{2}{c}{$\mathrm{Nt}(\mathrm{mg} / \mathrm{I})$} \\
& $1960-1970$ & $1990 \mathrm{~s}$ & $1960-1970$ & $1990 \mathrm{~s}$ \\
\hline River IJssel & 0.2 to $>0.4$ & $<0.1$ & $5-6.5$ & 3 \\
Lake IJsselmeer & $0.15-0.2$ & $<0.05$ & $3.5-4.5$ & 3 \\
Lake Markermeer & 0.07 & $0.005-0.02$ & 3 & 2 \\
\hline
\end{tabular}

Verder zijn er aanwijzingen dat in de pelagische zone nutrienten gemineraliseerd worden via fytoplankton (Brinkmann et al. 2019) en dat fosfaat wel in de bodem aanwezig is, maar slecht beschikbaar is voor het voedselweb doordat het in de mariene bodem aan calcium en ijzer gebonden zit (Saaltink 2018, van den Berg 2010, Van Riel et al. 2019). Ook de relatief hoge zwavelconcentraties in de bodem en de aanwezigheid van sulfide oxiderende bacterien (Bij de Vaate en Jansen 2011) zijn atypisch voor zoetwater meren en kunnen effect hebben op de biogeochemische processen in het meer (van der Welle et al. 2007, Vonk et al. 2017). In de ecologische analyse moeten deze factoren nader uitgewerkt worden.

\section{Soorten}

Voor soortensamenstelling, wordt in SESA ruwe monitoringsdata gebruikt. Wat soorten in het IJsselmeergebied betreft is vooral veel data beschikbaar over vogels en vissen. Ook wordt iedere zes jaar de Driehoeksmosselenpopulaties in het meer gemonitord (Bij de Vaate en Jansen 2012, 2016, Brongers 2001, Noordhuis 2000). Voor Dreissena soorten in het Markermeer en IJsselmeer zijn verspreidingskaarten beschikbaar (e.g. Figuur 8). De soortenaantallen en macrofaunadichtheid is laag in het Markermeer en IJsselmeer (Van Riel et al. 2018), maar beter ontwikkeld in de randmeren. Het is aannemelijk dat het aquatische voedselweb niet voldoende ontwikkeld is om aan de volledige voedselvraag van de Natura 2000 natuurdoelsoorten te voldoen (Lammens 2001, Van Riel et al. 2017). Er wordt in maatregelenpakketten veel ingezet op een verbetering van het voedselaanbod voor vogels. Dit vertaalt zich vooral in het aanbrengen van extra habitat voor prooidieren. Het is nog niet duidelijk of deze aanpak daadwerkelijk tot een verbetering van het aquatische voedselweb zal zorgen op de schaal die nodig is die de N2000 doelen vragen. Het is daarom uiterst belangrijk om te identificeren wat voor dit vraagstuk de relevante stuurknoppen om een ecologisch functionerend voedselweb te bereiken. De soortendichtheid en -diversiteit in het Markermeer en IJsselmeer zijn laag (Noordhuis 2010, Van Riel et al. 2019). Soorten zullen vanuit

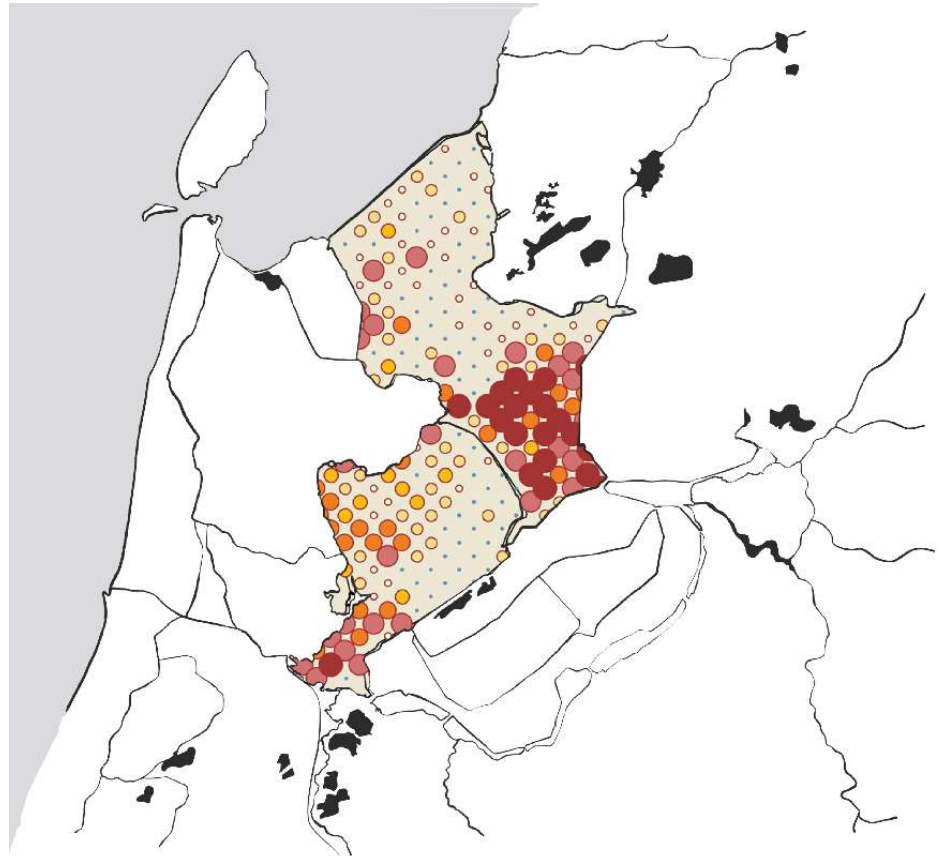

de directe omgeving de meren moeten kunnen bereiken om gebruik te kunnen maken van het nieuw aangelegde habitat. Op dit moment lijkt de macrofauna samenstelling veel op die van de grote rivieren, wat duidt op een instroom van vooral rivierfauna. Het is minder bekend hoe de uitwisseling tussen soorten binnen het in figuur 5 geschetste stroomgebied is. Over de verspreiding van waterplanten en algen worden data verzameld in het kader van het milieumeetnet rijkswateren chemie en biologie (MWTL-bemonstering). De data is niet gemakkelijk te raadplegen, maar zal opgevraagd moeten worden.

Figuur 8: De verspreiding van zoetwatermosselen (Dreissena) in het IJsselmeergebied. Naar Bij de Vaate (2011). 


\subsection{Sleutelfactoren invullen met beschikbare data}

In bovenstaande paragraaf is een grove schets gemaakt van factoren die in een stroomgebied brede ecologische analyse opgenomen moeten worden. Alle in figuur 3 benoemde sleutelfactoren dienen gekwantificeerd te worden. We hebben verkend welke optionele databronnen hiervoor geraadpleegd kunnen worden (Tabel 2).

Tabel 2: Overzicht van bruikbare databronnen voor stroomgebied brede analyse.

\begin{tabular}{|c|c|c|c|}
\hline Databron & Beschrijving & Type data & Gebied \\
\hline Ecotopenkaart & $\begin{array}{l}\text { Onderscheid in ecotopen op } \\
\text { basis van fysische gegevens }\end{array}$ & Morfologie & Hele stroomgebied \\
\hline MWTL data & $\begin{array}{lr}\text { Gegevens van } & \text { het } \\
\text { monitoringsnetwerk } & \text { van } \\
\text { Rijkswaterstaat } & \end{array}$ & Abiotisch en biotisch & Hele stroomgebied \\
\hline HABITAT & $\begin{array}{l}\text { Gebiedsmodel opgebouwd uit } \\
\text { verschillende rekenmodules }\end{array}$ & $\begin{array}{l}\text { Ruimtelijke kaartjes } \\
\text { met abiotische en } \\
\text { biotische gegevens per } \\
\text { locatie }\end{array}$ & $\begin{array}{l}\text { Markermeer, } \\
\text { IJmeer, IJsselmeer }\end{array}$ \\
\hline $\begin{array}{l}\text { Gegevens vanuit } \\
\text { Waterschappen }\end{array}$ & $\begin{array}{l}\text { Beschikbare meetgegevens uit } \\
\text { het gebied m.b.t. parameters uit } \\
\text { het } 5-\mathrm{S} \text { model }\end{array}$ & $\begin{array}{l}\text { Abiotisch en biotisch, } \\
\text { gekwantificeerde data }\end{array}$ & Hele stroomgebied \\
\hline Noordhuis 2010 & $\begin{array}{l}\text { Uitgebreide beschrijving van de } \\
\text { achtergrond en kenmerken van } \\
\text { de wateren in het } \\
\text { IJsselmeergebied. }\end{array}$ & $\begin{array}{l}\text { Historisch, fysisch- } \\
\text { chemisch, } \\
\text { morfologisch, biotisch }\end{array}$ & $\begin{array}{l}\text { Wateren in het } \\
\text { IJsselmeergebied }\end{array}$ \\
\hline
\end{tabular}

De ecotopen van het IJsselmeergebied geven aan wat voor typen habitat er in het gebied voorkomen. Figuur 9 geeft een overzicht van de karakterisering van de ecotopen van het IJsselmeergebied in 2013. Uit deze figuur blijkt dat de focus op de waterlichamen van het gebied lag (onderwater kolom, onderwaterbodem en directe oeverzone). Voor een stroomgebied brede analyse zullen ook de ecotopen in de polders en wateren die van invloed zijn op de meren inbegrepen worden. Dus ook de litorale zone (oeverzone) in bredere zin, de overstromingszone, en de aangrenzende terrestrische zone (omgeving).

\section{Ecotopen IJsselmeergebied}

Gegevens gebaseerd op data uit 2013. Marker Wadden dus nog niet hierin verwerkt

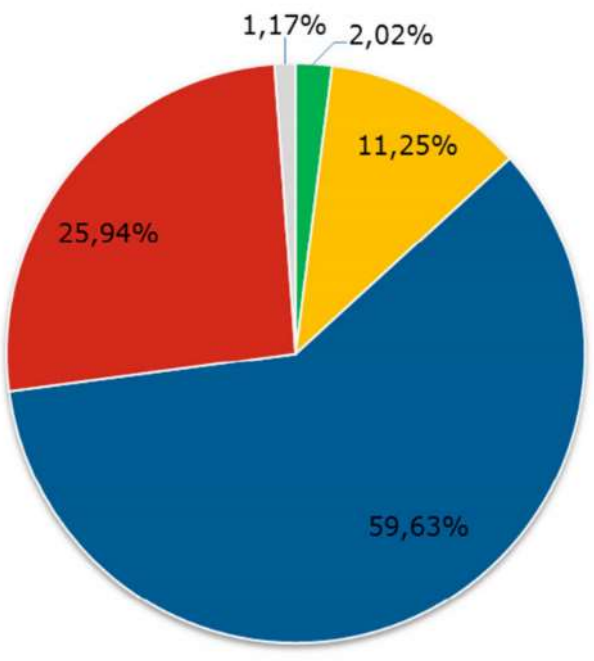

- Ondiep water $(<1 \mathrm{~m})$

matig diep water (1-3m)

- Diep water (3-5m)

- Zeer diep water $(>5 \mathrm{~m})$

$=$ Totaal overig

Figuur 9: Overzicht van de ecotopen in het IJsselmeergebied. Bron: Ministerie van I\&W, RWS (2017).

HABITAT is een gebiedsmodel dat de potentiële geschiktheid van het IJsselmeer en Markermeer/IJmeer berekent voor soorten op basis van ingevoerde fysisch/chemische gegevens en ecotopen. Figuur 10 geeft 
een overzicht van het model weer. Dit model is in 2005 opgezet (Haasnoot et al. 2009a, 2009b) en wordt met regelmaat aangepast naar de actuele situatie. Ook bij deze methode ligt de focus op het water gedeelte van het ecosysteem en op het samenbrengen van gegevens voor een locatie in het meer. De stroomgebiedsbrede ecologische systeemanalyse, afgekort als SESA, kan deze informatie gebruiken om het 5-S model mee te vullen, maar zal verder moeten zoeken naar informatie uit het litorale, overstromingsgebied en aangrenzende terrestrische zone. We hebben een eerste schets voor het betrekken van deze zones gemaakt, zie figuren 13 en 14. Ook zal bij SESA meer nadruk liggen op dynamische processen die het ecologisch functioneren bepalen en de samenhang tussen vormende en verstorende processen, met als doel de doorwerking van maatregelen efficiënt te voorspellen.

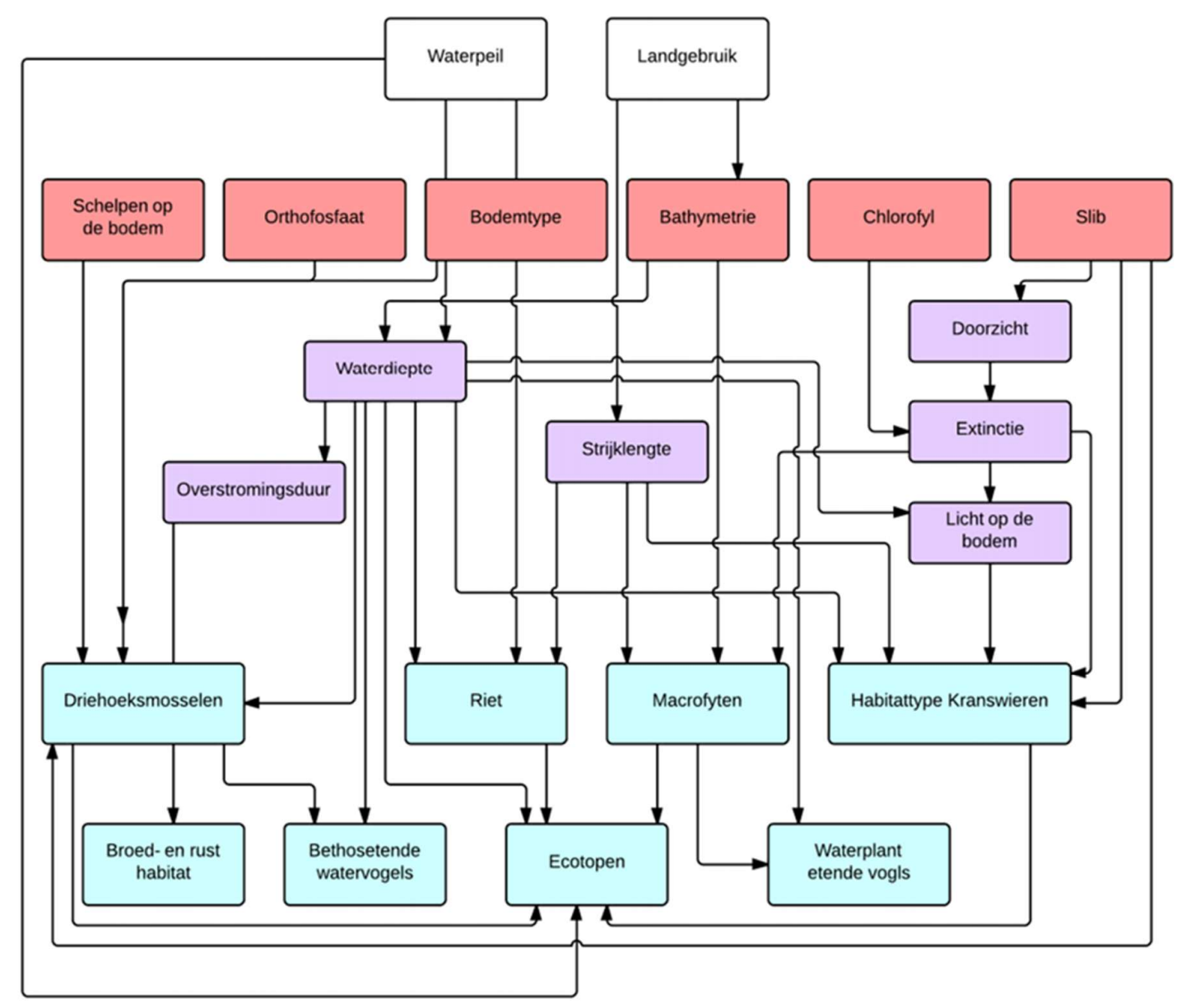

Figuur 10: Schematische weergave van de rekenmodules in de HABITAT-applicatie voor het IJsselmeergebied.

\section{$2.4 \quad$ Zoeken naar samenhang}

Een essentiële stap in de stroomgebiedsbrede ecologische analyse (SESA) is het zoeken naar de samenhang tussen de factoren. Hiervoor worden de verschillende S-en als het ware 'op elkaar gelegd' om een holistisch beeld van de sturende processen in het ecosysteem te krijgen, en de samenhang te begrijpen op de juiste schalen in ruimte en tijd. In deze stap wordt duidelijk hoe je kunt sturen op ecologisch functioneren. Het wordt duidelijk hoe een ingreep zich vertaalt naar verschillende schalen en verschillende factoren. Knelpunten zijn efficiënter te vast te stellen en aan te pakken vanuit geïntegreerde kennis van ecosysteemprocessen. Het flowdiagram in figuur 11 geeft aan hoe in een SESA invloedrijke cycli samen kunnen vallen, inzichtelijk gemaakt worden via ruimtelijke beelden waarop de stressoren op locatie weergegeven worden, en zo bijdragen aan concrete maatregelen om haalbare ecologische doelen te realiseren. In SESA kunnen sleutelfactoren als lagen gecombineerd worden in het model om de samenhang 
tussen stressoren te analyseren (figuur 2). De verkenning van de sleutelfactoren voor het ecosysteembreed functioneren en de samenhang tussen processen, zoals in de verkenning in paragraaf 2.2. naar voren gekomen, vormen de basis van de ruimtelijke weergave van het ecosysteem IJsselmeergebied in figuur 13 en 14. In figuur 14 is de vergelijking gemaakt van de landschappelijke inrichting van het IJsselmerengebied (Fig. 14a) met de opbouw van een natuurlijk merenecosysteem, waarbij de pelagische zone via een goed ontwikkelde littorale zone en moeras overgaat in een overstromingszone, begrensd door eeb natuurlijk begroeid landschap met struiken en bomen (Figuur 14b). In het landschap van het IJsselmerengebied, is de littorale zone onvoldoende ontwikkeld en wordt het open water begrensd door harde structuren als gevolg van bedijking. De bebouwde zone en het landelijk gebied grenzen aan de andere kant van de dijken. In vergelijking met de natuurlijke opbouw van een merenecosysteem, is het belangrijkste verschil dat de diversiteit, en overgangszone in de vorm van ondiepe waterzones, littoraal, moeras en natuurlijke oevers ontbreken.

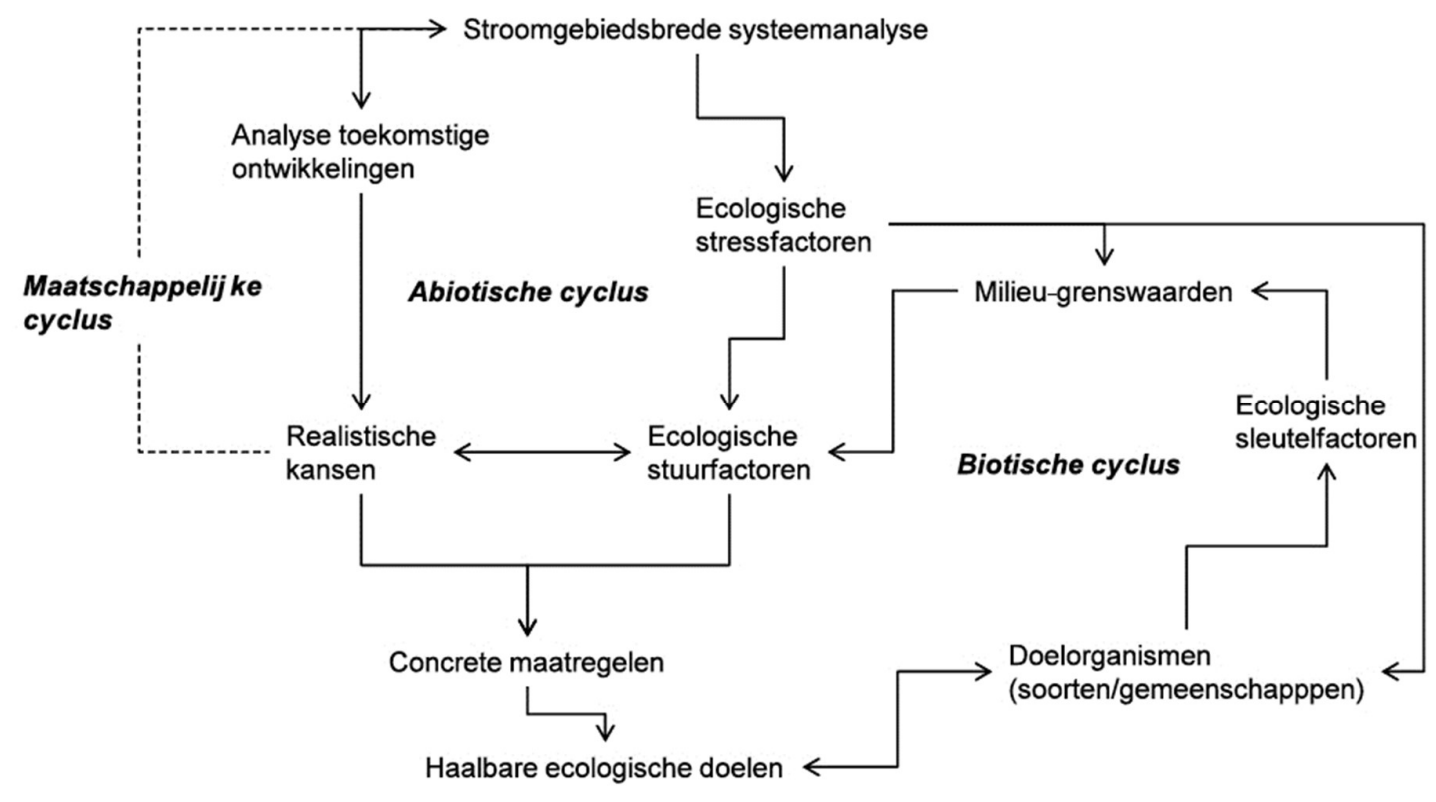

Figuur 11: Abiotische, biotische en maatschappelijke cycli in de stroomgebied brede ecologische systeemanalyse (SESA). Bron: Verdonschot et al. (2015).

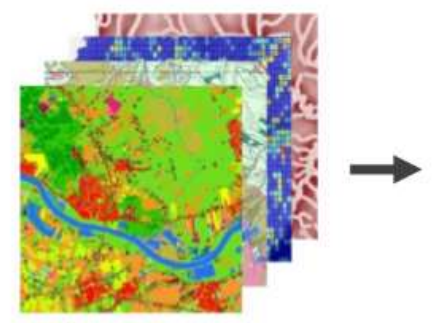

Stressor identification

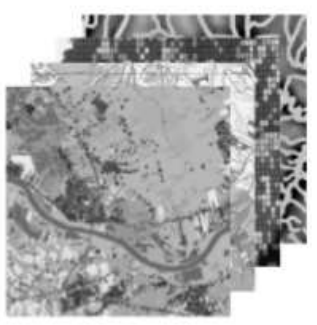

Stressors

classification

using impact-

based scores
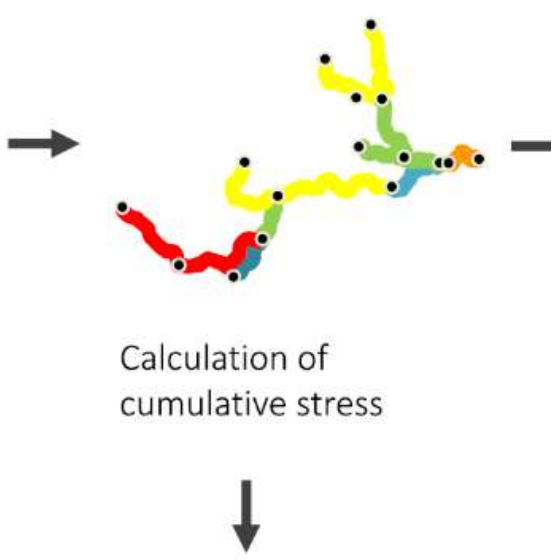

Identify and localize most stringent stressors

Figuur 12: Het SESA model combineert lagen met verschillende stressoren om de cumulatieve stress voor een waterecosysteem te analyseren. Bron: de Vries et al. (2019). 


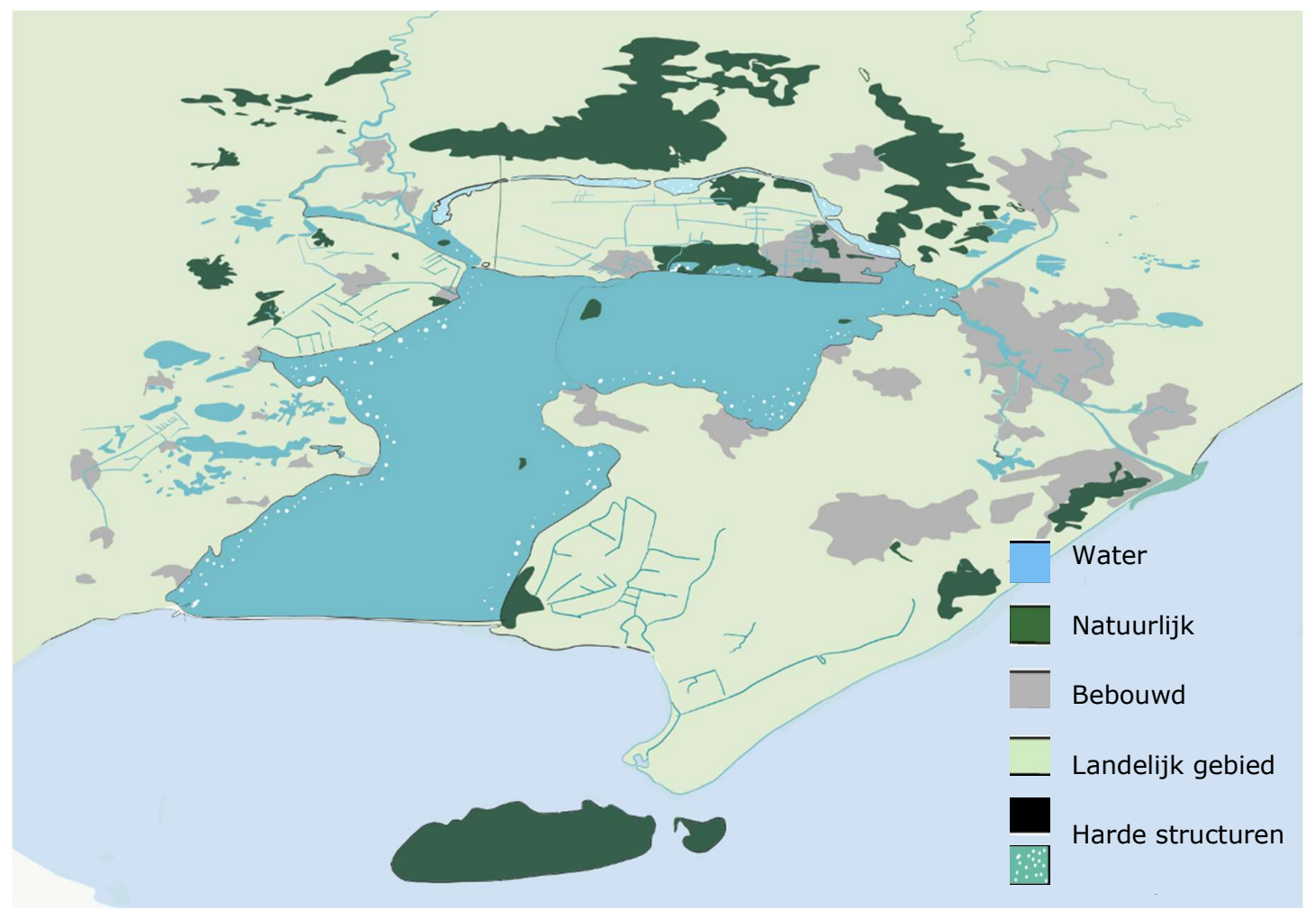

Figuur 13: Een ruimtelijk overzicht van het ecosysteem IJsselmeergebied, gebaseerd op de analyse van invloedrijke processen in sleutelfactoren uit paragraaf 2.2.

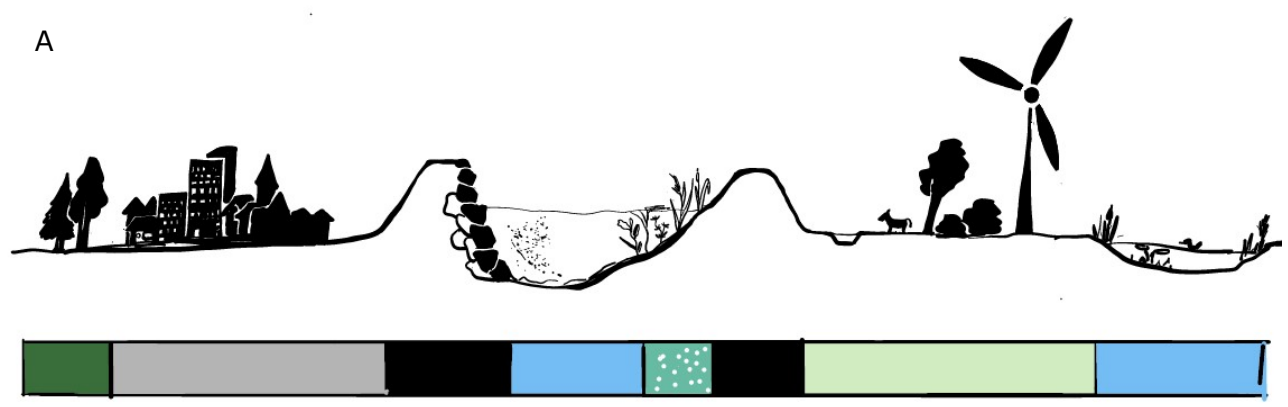

B

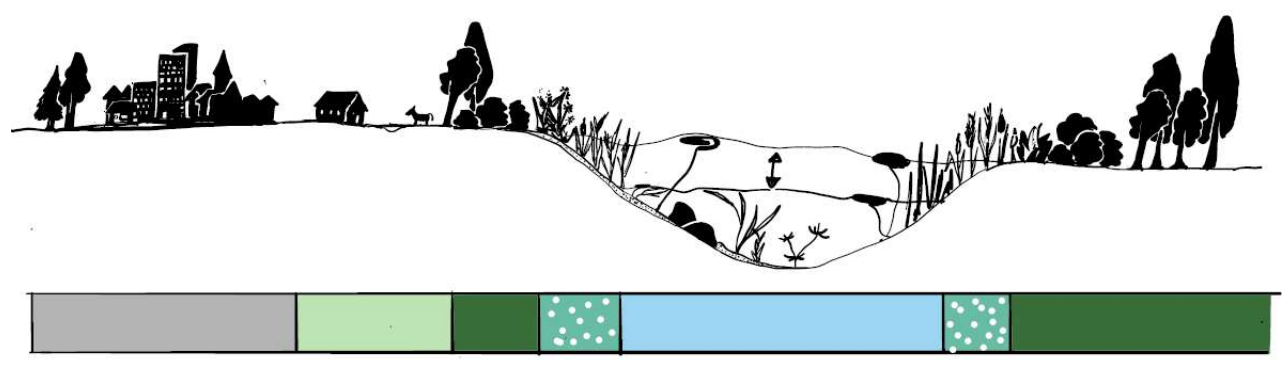

Figuur 14: Een schematische weergave van het landschappelijk verloop van a) het ecosysteem van het IJsselmeergebied ten opzichte van een b) een natuurlijk zoetwater meer ecosysteem. De kleuren in de kleurenbalk corresponderen met de kleurencode in van de landschappelijke weergave in figuur 13. 


\section{Conclusies en aanbevelingen}

- Er bestaan veel initiatieven voor maatregelpakketten om de situatie Natura 2000 doelen te bereiken en de waterkwaliteit, in de vorm van een verbeterde KRW-score, te verbeteren.

- Veel maatregelen focussen op extra habitat voor doelsoorten en compensaties voor de belemmering die de zeer artificiële en statische inrichting van het gebied vormt voor ecologische ontwikkeling. PAGW neemt daarnaast initiatief tot systeemingrepen.

- Veel ambities voor het gebied worden regionaal benaderd in plaats van stroomgebied breed.

- Het IJsselmeergebied is meer dan de meren alleen. Het omringende land en de omringende wateren behoren ook tot de ecologische invloeden (zie figuur 12). Een stroomgebiedsbrede ecologische analyse (SESA) beschouwd stuur-, sleutel-, en stressfactoren in het hele stroomgebied en analyseert het ecologisch functioneren van het gebied. Maatregelen kiezen vanuit de werking van een ecosysteem is een efficiënte en concrete methode om de ecologische processen van een verstoord ecosysteem te verbeteren.

- Ecotopen en HABITAT zijn waardevolle modellen om de geschiktheid van een locatie voor een soort te bepalen op historische observaties maar verklaren niet wat ecologische knelpunten voor deze soorten zijn m.b.t. ecologische functionaliteit. De toegevoegde waarde van SESA is het identificeren van functionele processen en het expliceren van de samenhang, vooral over meerdere schalen, tussen in spatiele modellen gebruikte variabelen.

- $\mathrm{Er}$ is veel gemeten en in de vorm van voorkomen, toestand- en verspreidingskaarten beschikbaar (denk aan MWTL-bemonstering, Noordhuis (2010), KRW-, en N2000 rapportages). Er bestaan al data geïntegreerde modellen (slibmodel, HABITAT). Er is data beschikbaar om een SESA mee te vullen, maar er bestaan ook diverse kennisleemten. Denk aan water- en stofstromen, productie in het meer zelf, informatie over macrofauna en voedselweb functioneren en samenhang tussen de meren en, vooral processen in het stroomgebied op grotere schaal, zoals kenbaar gemaakt in figuur 5 en 7.

- Ons advies is om functionele processen van het IJsselmeergebied gekwantificeerd in kaart te brengen. Het invullen van een 5-S model gebaseerde SESA voor het IJsselmeergebied (Figuur 3) geeft hier mogelijkheden voor. Vervolgens kunnen ecologische knelpunten geïdentificeerd worden en kunnen concrete maatregelen ontwikkeld worden om de ecologie te verbeteren.

Vragen als onderbouwing van de PAGW maatregelen die nu spelen gaan over hoe het ecosysteem kan functioneren in samenhang. Welke (grootschalige) maatregelen zijn er nodig, welke kleinschalige maatregelen hebben daarnaast veel impact. Tegelijkertijd lopen de PAGW maatregelen nu al en is er nu al een onderbouwing nodig. Aan deze onderbouwing en aan het in beeld brengen van het effect van de geprogrammeerde maatregelen op systeemniveau kan SESA een bijdrage leveren. De eerstvolgende stap hiervoor is het definiëren van het functionele ecosysteem IJsselmeergebied. De hydrologie en stoffenstromen naar en van het gebied zijn hiervoor de basis. In het WOT-project voor 2020 worden via waterbalansen de stromingen, peil en afvoer in beeld gebracht. Aan deze stromen worden concentraties stoffen (in eerste instantie nutrienten) gekoppeld die het gebied in- en uitgaan. Daarna wordt gekeken wat nodig is om de informatie, en respons completer en specfieker te maken. 


\section{$4 \quad$ Referenties}

Bij de Vaate A. en E.A. Jansen (2011) De dichtheid van driehoeks- en quaggamosselen in het Markermeer: resultaten van de kartering uitgevoerd in 2011. Deltares report 2011-03

Bij de Vaate A. en E.A. Jansen (2012) Driehoeks- en quaggamosselen in Marker- en IJsselmeer: resultaten van onderzoek uitgevoerd in de periode juni 2009 t/m juni 2012. Waterfauna Hydrobiologisch Adviesbureau, Lelystad, rapportnummer 2012/02.

Bij de Vaate A. en E.A. Jansen (2016) De dichtheid van quagga- en driehoeksmosselen in het Markermeer: resultaten van de kartering uitgevoerd in 2016.

Brinkmann, B. W., J. A. Vonk, S.A.M. van Beusekom, M. Ibanez, M.A. de Lucas Pardo, R. Noordhuis, H.G. van der Geest, H. G. (2019). Benthic hotspots in the pelagic zone: Light and phosphate availability alter aggregates of microalgae and suspended particles in a shallow turbid lake. Limnology and Oceanography, 64(2): 585-596. https://doi.org/10.1002/Ino.11062

Brongers I. (2001) Inventarisatie driehoeksmosselen Markermeer 2000. Rijkswaterstaat-RDIJ report 20014, 99pp.

Lammens (2001) Het voedselweb van IJsselmeer en Markermeer. De levende natuur 102 (5): 210-214

Noordhuis R. (red.) (2000) Biologische monitoring zoete rijkswateren: Watersysteemrapportage IJsselmeer en Markermeer. RIZA report 2000.050

BVR adviseurs ruimtelijke ontwikkeling (2008) Ontwikkelingsvisie 2030 Zuidelijke Randmeren. 74 pp.

Haasnoot, M., J.S. Verkade en K.M de Bruijn (2009a) HABITAT as spatial analysis tool for ecological impact and damage assessment. In: Hydroinformatics. Concepcion, Chili

Haasnoot, M. en K. Van der Wolfshaar(2009b) Combining a conceptual framework and a spatial analysis tool, habitat, to support the implementation of river basin management plans. Int J River Basin Management 7:295-311

Maarse, M. (2014) HABITAT gebiedsmodel IJsselmeer en Markermeer. Modelopzet en validatie. Deltares rapport $1207726-000,40 \mathrm{pp}$.

Ministerie van Infrastructuur en Waterstaat, Rijkswaterstaat (2017) Preverkenning IJsselmeergebied. Achtergronddocument Preverkenning ecologische kwaliteit IJsselmeergebied. Eindconcept rapport, versie 20171201

Ministerie van Infrastructuur en Waterstaat (2018) IJsselmeergebied 2050, Uitvoerings-, kennis- en innovatieagenda 2019-2020, 27 pp.

Ministerie van Landbouw, Natuur en Visserij (2009) Besluit Natura-2000 gebied Markermeer \& IJmeer. PDN/2009-073.

Noordhuis, R. (red.) (2000) Biologische monitoring zoete rijkswateren: Watersysteemrapportage IJsselmeer en Markermeer. RIZA report 2000.050

Noordhuis, R. (2010) Ecosysteem IJsselmeergebied: nog altijd in ontwikkeling. Trends en ontwikkelingen in water en natuur van het Natte Hart van Nederland. Rijkswaterstaat Waterdienst, Lelystad.

Noordhuis, R., ,S. Groot, M. Dionisio Pires en M. Maarse (2014) Wetenschappelijk eindadvies ANTIJsselmeergebied. Vijf jaar studie naar kansen voor het ecosysteem van het IJsselmeer, Markermeer en IJmeer met het oog op de Natura-2000 doelen. Deltares Report 1207767-000ZWS-0005, $82 \mathrm{pp}$.

Platteeuw, M., W. Iedema, C. Breukers en K. Hartnack (2018) Nota: Naar duurzaam ecologisch beheer. Maatregelpakket bij het beheerplan Natura2000 IJsselmeergebied. Onderliggende Nota bij het beheerplan N2000 IJsselmeergebied. RWS document, 14 pp.

Rijkswaterstaat, Ministerie van Infrastructuur en Milieu (2017a) Natura 2000 Beheerplan IJsselmeergebied 2017 - 2023, Zwarte meer. RWS rapport WD1017LL053

Rijkswaterstaat, Ministerie van Infrastructuur en Milieu (2017b) Natura 2000 Beheerplan IJsselmeergebied 2017 - 2023, IJsselmeer. RWS rapport WD1017LL055

Rijkswaterstaat, Ministerie van Infrastructuur en Milieu (2017c) Natura 2000 Beheerplan IJsselmeergebied 2017 - 2023; Markermeer en IJmeer. Rijkswaterstaat rapport, WD1017LL057, 64 pp.

Rijkswaterstaat, Ministerie van Infrastructuur en Milieu (2017d) Natura 2000 Beheerplan IJsselmeergebied 2017 - 2023, Veluwerandmeren. RWS rapport WD1017LL059

Rijkswaterstaat (2019) Programmatische Aanpak Grote Wateren. Verder met de verbetering van ecologische waterkwaliteit. Rijkswaterstaat rapport PPO0419KK102

Saaltink, R. (2018) Wetland eco-engineering with fine sediment. PhD thesis, $259 \mathrm{pp}$.

Van den Berg, L.J.L., M.C. van Riel en L. Bakker (2014) MarkerMeerMoeras: Nieuwe Kansen voor Natura 2000. CWE, Rijkswaterstaat rapport 2014.01 
Van der Geest, H.G., J.A. Vonk en M. Ouboter (2018) Reconstructie water- en stoffenbalans Markermeer 1976-2015. Universiteit van Amsterdam en Waternet rapport

Van der Welle, M.E.W., A.J.P. Smolders, H.J.M. Op den Camp en L.P.M. Lamers (2007) Biogeochemical interactions between iron and sulphate in freshwater wetlands and their implications for interspecific competition between aquatic macrophytes. Freshwater Biology 52(3): 434-447

Van Luijn, F. en E. Rijsdijk, Ministerie van Verkeer en Waterstaat, Rijkswaterstaat IJsselmeergebied (RWS IJG) (2006) Risico-analyse KRW IJsselmeergebied: achtergronddocument: implementatie van de Europese Kaderrichtlijn Water in het IJsselmeergebied. IJG-werkdocument 2006-14, 27 pp.

Van Riel, M.C., M.F. Leopold en H.E. Keizer-Vlek (2017) Notitie 'Natuurambitie in de praktijk' Stand van natuurdoelen in het Markermeer en gevolgen van de ontwikkeling van de Marker Wadden. Notitie Zoetwaterecosystemen, Wageningen Environmental Research, Wageningen UR, Wageningen. 49 pp.

van Riel, M.C., Verdonschot P.F.M en Dekkers D.D. (2018) Markermeer bodemfaunakartering 2016 en MWTL-analyse MWTL data. Notitie Zoetwaterecosystemen, Wageningen Environmental Research, Wageningen UR, Wageningen. 48 pp.

Van Riel, M.C., J.A. Vonk, R. Noordhuis, and P.F.M. Verdonschot (2019) Novel ecosystems in urbanized areas under multiple stressors: Using ecological history to detect and understand ecological processes of an engineered ecosystem (lake Markermeer). Notitie Zoetwaterecosystemen, Wageningen Environmental Research, Wageningen UR, Wageningen. 34 pp.

Van Rijn, S., M. Menken en M. Platteeuw (2010) Doeluitwerking Natura 2000 IJsselmeergebied. Waterdienst Rijkswaterstaat, Lelystad.

Verdonschot, P.F.M. (2009) Het brede beekdal als klimaatbestendige buffer in de veranderende leefomgeving: flexibele toepassing van het 5B-concept in Peel en Maasvallei. 64 pp.

Verdonschot, P. F. M., R.C.M. Verdonschot en A.A. Besse-Lototskaya (2015) ESF stromende wateren en stroomgebiedsbrede ecologische systeemanalyse. $\mathrm{H} 2 \mathrm{O}$ online, 28 aug 2015

Vonk, J.A., T. Rombouts, J.C. Schoorl, P. Serne, J.W. Westerveld, P. Cornelissen, and H.G. van der Geest (2017) Impact of water drawdown and rewetting on sediment nutrient dynamics in a constructed delta-lake system (Oostvaardersplassen, The Netherlands): A mesocosm study. Ecological Engineering, http://dx.doi.org/10.1016/j.ecoleng.2017.06.017

de Vries J., M..H.S. Kraak, R.C.M. Verdonschot, en P.F.M. Verdonschot (2019) Quantifying cumulative stress acting on macroinvertebrate assemblages in lowland streams Science of the Total Environment 694: 1-11 


\section{Bijlage 1: Status van de N2000 doelen voor het IJsselmeergebied}

Bron: Rijkswaterstaat, Ministerie van Infrastructuur en Milieu 2017a-d

\begin{tabular}{|c|c|c|c|c|c|c|c|c|c|c|c|c|}
\hline \multirow[b]{2}{*}{ 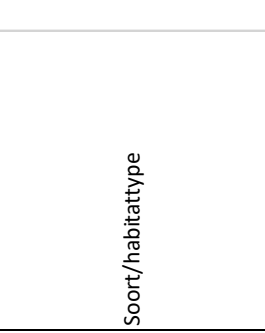 } & \multicolumn{4}{|c|}{ VELUWERANDMEREN } & \multicolumn{4}{|c|}{ KETEL- \& VOSSEMEER } & \multicolumn{4}{|c|}{ ZWARTEMEER } \\
\hline & 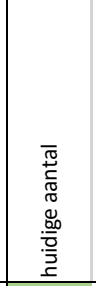 & $\begin{array}{l}\bar{\pi} \\
\stackrel{\pi}{\pi} \\
\frac{\pi}{\pi} \\
\frac{0}{d} \\
\frac{0}{0}\end{array}$ & 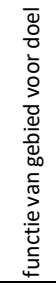 & 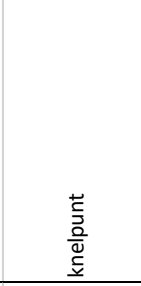 & 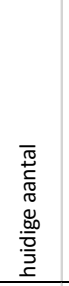 & $\begin{array}{l}\bar{\pi} \\
\stackrel{\pi}{2} \\
\frac{\pi}{\pi} \\
\frac{\pi}{2} \\
\frac{0}{0} \\
\end{array}$ & 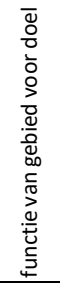 & 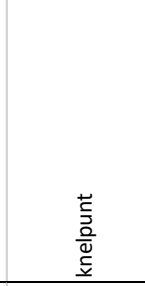 & 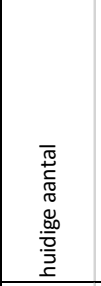 & $\begin{array}{l}\bar{\pi} \\
\stackrel{\pi}{c} \\
\frac{\pi}{\pi} \\
\frac{\pi}{0} \\
\frac{0}{0} \\
\end{array}$ & 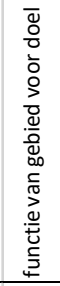 & 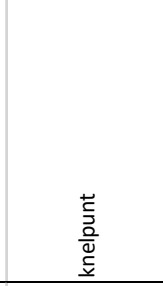 \\
\hline Kranswierwateren & 2965 ha & & & - & & & & & & & & \\
\hline $\begin{array}{l}\text { Meren met krabbenscheer } \\
\text { en fonteinkruiden }\end{array}$ & 18 ha & & & - & & & & & & & & \\
\hline Meervleermuis & 100-den & - & $\mathrm{F}$ & - & & & & & 100-den & & $\mathrm{F}$ & \\
\hline Rivierdonderpad & ? & - & & - & & & & & ? & & FRV & \\
\hline Aalscholver & 611 & 420 & FS & - & 707 & 870 & $\mathrm{~F}$ & voedsel & 315 & 330 & $F$ & voedsel \\
\hline Brilduiker & 105 & 220 & $\mathrm{~F}$ & voedsel, rust & & & & & & & & \\
\hline Fuut & 450 & 400 & $\mathrm{~F}$ & - & 257 & 350 & $\mathrm{~F}$ & voedsel & 98 & 170 & $\mathrm{~F}$ & voedsel extern \\
\hline Grote zaagbek & 40 & 50 & $\mathrm{~F}$ & voedsel, rust & 27 & 70 & $\mathrm{~F}$ & voedsel & & & & \\
\hline Kuifeend & 7093 & 5700 & $\mathrm{~F}$ & & 2267 & 4500 & $\mathrm{~F}$ & voedsel, rust & 1199 & 1700 & $\mathrm{~F}$ & voedsel extern \\
\hline Meerkoet & 11705 & 11000 & $\mathrm{~F}$ & - & 1747 & 17000 & $\mathrm{~F}$ & voedsel, rust & 1251 & 1800 & $\mathrm{~F}$ & voedsel extern \\
\hline Nonnetje & 44 & 60 & $\mathrm{~F}$ & voedsel, rust & 17 & 30 & $\mathrm{~F}$ & voedsel & & & & \\
\hline Slobeend & 31 & 50 & $\mathrm{~F}$ & voedsel, rust & & & & & 13 & 10 & $\mathrm{~F}$ & - \\
\hline Tafeleend & 3719 & 6600 & $\mathrm{~F}$ & voedsel, rust & 243 & 350 & $\mathrm{~F}$ & - & 78 & 240 & $\mathrm{~F}$ & voedsel extern \\
\hline Zwarte stern & & & & & & & & & ? & 10 & $\mathrm{~F}$ & voedsel extern \\
\hline Visarend & & & & & 3 & 3 & $\mathrm{~F}$ & - & & & & \\
\hline $\begin{array}{l}\text { Meren met krabbenscheer } \\
\text { en fonteinkruiden }\end{array}$ & & & & & & & & & 50 ha & & & \\
\hline Kleine modderkruiper & hekend & & & - & & & & & ? & & FRV & \\
\hline Kleine zwaan & 335 & 120 & FS & - & 0 & 5 & FS & - & 0 & 2 & FS & extern \\
\hline Krakeend & 459 & 280 & $\mathrm{~F}$ & - & 718 & 160 & $\mathrm{~F}$ & - & 379 & 90 & $\mathrm{~F}$ & - \\
\hline Lepelaar & 8 & 3 & $\mathrm{~F}$ & - & 13 & 8 & $\mathrm{~F}$ & - & 2 & 3 & $\mathrm{~F}$ & - \\
\hline Pijlstaart & 217 & 140 & $\mathrm{~F}$ & - & 30 & 50 & $\mathrm{~F}$ & extern & 3 & 10 & $\mathrm{~F}$ & voedsel \\
\hline Smient & 2829 & 3500 & FS & extern & & & & & 628 & 1300 & S & extern \\
\hline Krooneend & 69 & 30 & $\mathrm{~F}$ & - & & & & & & & & \\
\hline Grote zilverreiger & 86 & 40 & $\mathrm{~S}$ & - & & & & & & & & \\
\hline Grauwe gans & & & & & 1277 & 680 & FS & & 887 & 630 & FS & \\
\hline Kolgans & & & & & 316 & 220 & FS & & 602 & 740 & FS & \\
\hline Toendrarietgans & & & & & ? & ? & $\mathrm{S}$ & & ? & ? & $S$ & \\
\hline Wintertaling & & & & & 158 & 360 & $\mathrm{~F}$ & & 121 & 470 & $\mathrm{~F}$ & \\
\hline Reuzenstern & & & & & $?$ & 7 & FS & & & & & \\
\hline $\begin{array}{l}\text { Ruigten en zomen A } \\
\text { (moerasspirea) }\end{array}$ & & & & & & & & & $<0.5$ ha & & & kennis habitat \\
\hline Porseleinhoen bv & & & & & 0.4 & 4 & FRV & leefgebied & 0.5 & 7 & FRV & leefgebied \\
\hline Rietzanger bv & & & & & & & & & ? & 270 & FRV & leefgebied \\
\hline Roerdomp bv & 2 & 5 & FRV & leefgebied & 0.6 & 5 & FRV & leefgebied & 2 & 6 & FRV & leefgebied \\
\hline Snor bv & & & & & & & & & ? & 50 & FRV & leefgebied \\
\hline Grote Karekiet bv & 27 & 40 & FRV & leeefgebied & 22 & 40 & FRV & leefgebied & 29 & 40 & FRV & leefgebied \\
\hline Purperreiger bv & & & & & & & & & 0.6 & 20 & FRV & leefgebied \\
\hline Grote modderkruiper & & & & & & & & & $?$ & & $\mathrm{FV}$ & leefgebied \\
\hline $\begin{array}{l}\text { Glanshaver- en } \\
\text { vossenstaarthooilanden } \\
\text { (grote vossenstaart) }\end{array}$ & & & & & & & & & $<1$ ha & nvt & & aangetast \\
\hline Grutto & & & & & 35 & 20 & FS & & ? & behoud & $\mathrm{S}$ & \\
\hline
\end{tabular}




\begin{tabular}{|c|c|c|c|c|c|c|c|c|c|}
\hline \multirow[b]{2}{*}{ 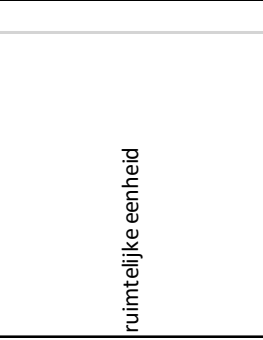 } & \multirow[b]{2}{*}{ 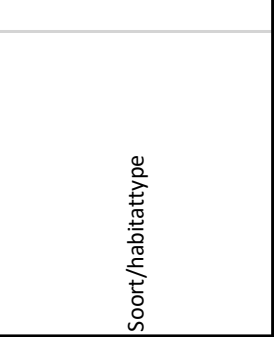 } & \multicolumn{4}{|c|}{ IJSSELMEER } & \multicolumn{4}{|c|}{ MARKERMEER IJMEER } \\
\hline & & 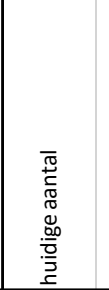 & $\begin{array}{l}\bar{\pi} \\
\stackrel{\pi}{0} \\
\frac{\pi}{\pi} \\
\frac{0}{0} \\
\frac{0}{0}\end{array}$ & 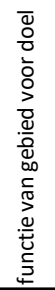 & 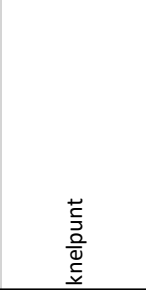 & 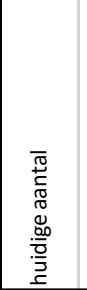 & $\begin{array}{l}\bar{\pi} \\
\stackrel{\pi}{ \pm} \\
\frac{0}{0} \\
\frac{\pi}{0} \\
\bar{D} \\
\frac{0}{0}\end{array}$ & 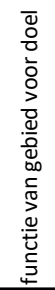 & 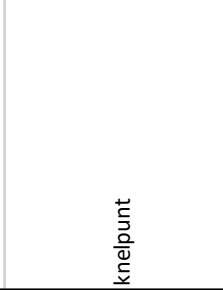 \\
\hline \multirow{16}{*}{ Open water } & Kranswierwateren & & & & & 685 ha & & & \\
\hline & Meervleermuis & 100-den & - & $\mathrm{F}$ & - & ? & - & $\mathrm{F}$ & - \\
\hline & Rivierdonderpad & ? & - & FRV & - & & & & \\
\hline & Aalscholver & 10322 & 8100 & $F$ & - & ? & - & FRV & - \\
\hline & Brilduiker & 504 & 310 & $\mathrm{FR}$ & - & 3524 & 2600 & FRV & - \\
\hline & Dwergmeeuw & ? & 85 & $\mathrm{~F}$ & voedsel & 86 & 170 & $\mathrm{~F}$ & voedsel \\
\hline & Fuut & 1127 & 2200 & $F R$ & voedsel & ? & & $\mathrm{F}$ & voedsel \\
\hline & Grote zaagbek & 1913 & 1850 & FR & - & 171 & 170 & $\mathrm{~F}$ & rust, ruimte, voedsel \\
\hline & Kuifeend & 10113 & 11300 & $F R$ & voedsel, rust & 53 & 40 & $\mathrm{~F}$ & rust, ruimte, voedsel \\
\hline & Meerkoet & 5894 & 3600 & FR & - & 15873 & 18800 & $\mathrm{~F}$ & rust, ruimte, voedsel \\
\hline & Nonnetje & 235 & 180 & FR & - & 7225 & 4500 & $\mathrm{~F}$ & - \\
\hline & Reuzenstern & 61 & 40 & FS & - & 95 & 80 & $\mathrm{~F}$ & rust, ruimte, voedsel \\
\hline & Slobeend & 86 & 60 & FR & - & & & & \\
\hline & Tafeleend & 824 & 310 & $F R$ & - & 39 & 20 & $\mathrm{~F}$ & - \\
\hline & Topper & 13444 & 15800 & FR & - & 6493 & 3200 & $\mathrm{~F}$ & rust, ruimte, voedsel \\
\hline & Zwarte stern & 16536 & 73200 & FS & voedsel, rust & 97 & 70 & $\mathrm{~F}$ & - \\
\hline \multirow{11}{*}{ ondiep water } & $\begin{array}{l}\text { Meren met krabbenscheer } \\
\text { en fonteinkruiden }\end{array}$ & 35 ha & & & & & & & \\
\hline & Bergeend & 197 & 210 & FR & rust & & & & \\
\hline & Kleine zwaan & $134 / ? p$ & pplaatsen & FRS & - & & & & \\
\hline & Kluut & 43 & 20 & $\mathrm{FR}$ & - & & & & \\
\hline & Krakeend & 461 & 200 & $F R$ & - & & & & \\
\hline & Lepelaar & 60 & 30 & $\mathrm{FR}$ & - & & & & \\
\hline & Pijlstaart & 64 & 60 & $\mathrm{R}$ & - & 7 & 2 & $\mathrm{~F}$ & rust \\
\hline & Smient & 6399 & 10300 & $F R$ & extern & & & & \\
\hline & Wilde eend & 1630 & 3800 & $F R$ & rust, voedsel & & & & \\
\hline & Krooneend & & & & & 10 & $?$ & $\mathrm{~F}$ & - \\
\hline & Grote zilverreiger & & & & & & & & \\
\hline \multirow{4}{*}{ oeverzone } & Grauwe gans & 2945 & 580 & $F R$ & & & & & \\
\hline & Kleine rietgans & 0,2 & 30 & RS & rust, extern & 1174 & 510 & FR & - \\
\hline & Toendrarietgans & ? & geen & RS & & & & & \\
\hline & Wintertaling & 313 & 280 & $\mathrm{FR}$ & & & & & \\
\hline \multirow{3}{*}{$\begin{array}{c}\text { kale of schaars begroeide } \\
\text { gronden }\end{array}$} & Bontbekplevier bv & 13 & 13 & $\mathrm{RV}$ & successie & & & & \\
\hline & Visdief bv & 5330 & 3300 & $\mathrm{RV}$ & successie & 247 & 630 & $\mathrm{FV}$ & voedsel \\
\hline & Zwarte stern & & & & & ? & ? & FR & voedsel \\
\hline \multirow{12}{*}{ moeras } & $\begin{array}{l}\text { Ruigten en zomen A } \\
\text { (moerasspirea) }\end{array}$ & $<1$ ha & + & & peilregime & & & & \\
\hline & $\begin{array}{l}\text { Ruigten en zomen B (Harig } \\
\text { wilgenroosje) }\end{array}$ & ? & - & & peilregime & & & & \\
\hline & Overgangs- en trilvenen A & $4 \mathrm{ha}^{2}$ & -- & & peilregime & & & & \\
\hline & Groenknolorchis & 0 & -- & & peilregime & & & & \\
\hline & Noordse woelmuis & ? & -- & $\mathrm{FV}$ & & & & & \\
\hline & Aalscholver bv & ca 7000 & 8000 & RV & onduidelijk & 5500 & 8000 & $\mathrm{~F}$ & voedsel \\
\hline & Bruine kiekendief bv & 10 & 25 & $\mathrm{FV}$ & leefgebied & & & & \\
\hline & Lepelaar bv & 84 & 25 & FRV & & & & & \\
\hline & Porseleinhoen bv & 0 & 18 & FV & rietmoeras & & & & \\
\hline & Rietzanger bv & ? & 990 & $\mathrm{FV}$ & & & & & \\
\hline & Roerdomp bv & 5 & 7 & FRV & leefgebied & & & & \\
\hline & Snor bv & ? & 40 & $\mathrm{FV}$ & & & & & \\
\hline \multirow{9}{*}{ nat grasland } & Brandgans & $23 / 703755$ & $500 / 26200$ & FRS & & 1249 & 160 & $\mathrm{FR}$ & \\
\hline & Goudplevier & 507 & 9700 & $\mathrm{FR}$ & extern & & & & \\
\hline & Grutto & $160 / 2132$ & $290 / 2200$ & FRS & extern & & & & \\
\hline & Kemphaan bv & 1 & 20 & FRV & extern & & & & \\
\hline & Kemphaan & $198 / 33531$ & $100 / 17300$ & FRS & extern & & & & \\
\hline & Kolgans & $896 / ? 4$ & $400 / 19000$ & RS & extern & & & & \\
\hline & Wulp & $898 / 4398$ & $310 / 3500$ & FRS & & & & & \\
\hline & Krakeend & & & & & 222 & 90 & $\mathrm{~F}$ & \\
\hline & Smient & & & & & 7416 & 15600 & $\mathrm{R}$ & rust \\
\hline
\end{tabular}


